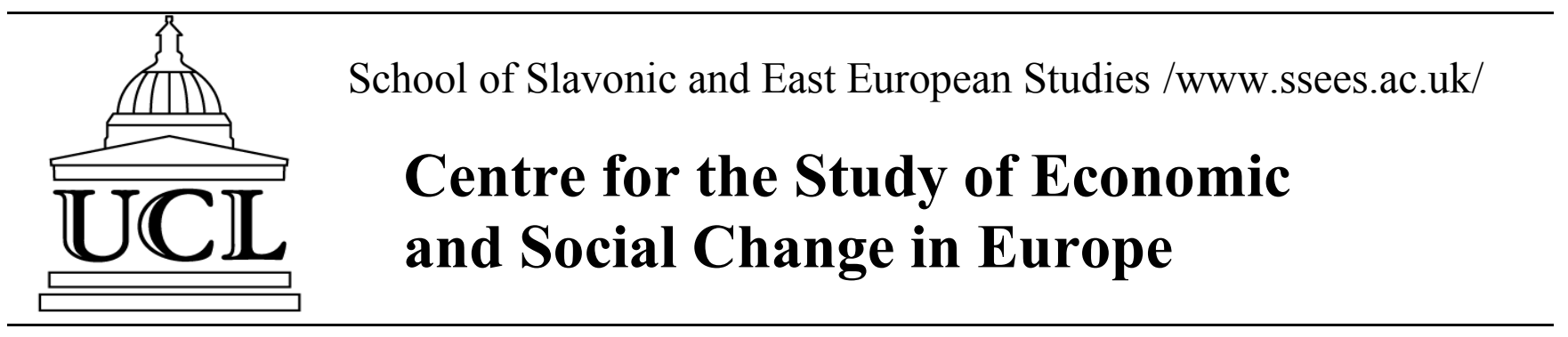

\title{
CREATIVE DESTRUCTION AND TRANSITION: THE EFFECTS OF FIRM ENTRY AND EXIT ON PRODUCTIVITY GROWTH IN ESTONIA
}

\author{
Jaan Masso, Raul Eamets and Kaia Philips
}

\section{University College London}

School of Slavonic and East European Studies

Working Paper Series No ...

Key words: firm survival, firm entry and exit, productivity decompositions, Estonia June 2004

University College London School of Slavonic and East European Studies Senate House, Malet Street, London, WC1E7HU Tel: 44(0)20 76368000 (Switchboard) Fax: 44(0)20 78628642 http://www.ssees.ac.uk/economic.htm 


\title{
CREATIVE DESTRUCTION AND TRANSITION: THE EFFECTS OF FIRM ENTRY AND EXIT ON PRODUCTIVITY GROWTH IN ESTONIA
}

\author{
Jaan Masso, Raul Eamets and Kaia Philips ${ }^{1}$
}

\section{Introduction}

The enterprise sector is expected to be dynamic and turbulent during the transition from socialist to market economy. High labour market flexibility is needed at the micro level, so that both jobs and workers can move from "old" sectors and firms to "new" ones in order to ensure resource reallocation and productivity growth. The literature shows that aggregate productivity growth occurs in addition to technological and organizational changes occurring due to the reallocation of production factors from low-productivity production units to highproductivity units (see e.g. Ahn 2001). Though economic theory often exploits the paradigm of a representative firm, the empirical literature has convincingly documented wide heterogeneity in the behaviour of individual firms even within narrowly defined industries (Bartelsman et al. 2003). For example, many firms enter and exit markets every year. Among entering firms, many fail to survive during the first years while others grow rapidly. Even in expanding industries many firms decline and in contracting industries, rapidly growing firms can be found. Concerning labour demand, changes in employment due to plant openings and closings are as important as changes due to expansions and contractions in continuing firms (Hamermesh 1993).

Economic theory offers some explanations of these stylized facts. Theories arising from Schumpeter's process of creative destruction (see e.g. Aghion and Howitt 1992) state that new

\footnotetext{
${ }^{1}$ Jaan Masso (corresponding author). Ph.D student, University of Tartu, Faculty of Economics and Business Administration, Narva mnt. 4-A110, 51009 Tartu, Estonia, E-mail. Jaan.Masso@mtk.ut.ee

Raul Eamets. Ph.D, Associate Professor of Economics, University of Tartu, Faculty of Economics and Business Administration, Narva mnt. 4-A210, 51009 Tartu, Estonia, E-mail: Raul.Eamets@mtk.ut.ee

Kaia Philips: Ph.D, Associate Professor of Economics, University of Tartu, Faculty of Economics and Business Administration, Narva mnt. 4-A210, 51009 Tartu, Estonia, E-mail. Kaia.Philips@mtk.ut.ee

The results presented in the paper have been partly produced as a part of the World Bank firm level project. We thank Eric Bartelsman from Vrije Universiteit Amsterdam for several comments and discussions on the methodology during our participation in the aforementioned project, and for providing the computer programs used in the analysis. We are grateful to Karsten Staehr, Tõnu Roolaht, Otto Karma, Rena Selliov, Ken Smith and participants of the seminar "Estonia - growth and restructuring of a new EU member" in University College London (especially Wendy Carlin) for many helpful comments. We also thank Janno Järve from Estonian Ministry of Economic Affairs and Communications and Indrek Künnapas from Ministry of Justice Centre of Registers for information on the Estonian Business Registry data. We are solely responsible for errors, inconsistencies etc, and all criticisms should be addressed to us only.
} 
technologies and innovations are introduced by new firms, which, if successful, replace incumbent firms. Active and passive learning models (see respectively Jovanovic 1982 and Ericson and Pakes 1995) explain how experimentation under uncertainty about the demand for new products or the cost effectiveness of alternative technologies creates micro-level heterogeneity and firm dynamics. The product life cycle model argues that in a given industry the number of firms and their average size change over the product life cycle (Ahn 2001).

Studies of the impact of job reallocation on aggregate productivity growth mostly have been carried out in the U.S. and they tend to find a positive relationship, although results depend somewhat on data and measurement methods. Previous studies of job flows in the transition contain relatively little information on the relationship between job flows and productivity. Studies from transition countries include Brown and Earle (2002) who have analysed this relationship for Russia and Ukraine and De Loecker and Konings (2003) who have studied Slovenia. Both these studies analyse the manufacturing sector and the results of these studies assert that the transition process has led firms to engage in more restructuring, not just destroying jobs, but also creating jobs, contributing to gains in firm level productivity. Brown and Earle (2004) studied productivity enhancing reallocation for Russia and Ukraine. They showed that while in Soviet Russia the reallocation rates were low and bore little relation to relative labour and multifactor productivity across firms, after reforms increasing resource flows have contributed to aggregate productivity growth through both increased flows from less productive to more productive continuing firms and the exits of less productive enterprises. Orazem and Vodopivec (2003) showed for Slovenian manufacturing, that competitive pressures sorted out the most efficient firms and the entry of efficient new private firms was the major source of total factor productivity (TFP hereafter) gains. De Loecker and Konings (2003) calculated for Slovenia that more than $40 \%$ of average productivity growth in Slovenian manufacturing was due to firm entry and exit Warzinski (2002) showed for Poland, that more job reallocation was connected with more productive industries.

In this paper we analyse the entry and exit, and the changes in employment among incumbent firms and their productivity development. Documenting firm demographics in Estonia, helps to understand how changes in firm demographics have contributed to the country's economic development and to identify the peculiarities of firm dynamics. Several previous studies ${ }^{2}$ have documented high gross flows of jobs in Estonia, but there is still a question whether this 
process represents creative destruction, which involves substantial gross job reallocation and where we would observe a decline of unproductive jobs simultaneously with an increase of new productive jobs.

There are also several other motives for studying productivity dynamics in Estonia. Labour productivity, though growing rapidly, amounted to less than $40 \%$ of the EU average in all three Baltic countries in 1998 (EUROSTAT, 2001). So far low wage levels have accompanied low productivity. According to Eurostat, hourly labour costs in Estonian industry were 2.90 euro, while the candidate countries' average was 3.25 and the EU average was 23.00 euro in 2000 (Clare and Paternoster 2002). However, this advantage of low labour compensation will not last forever. After Estonia joins the EU, extra upward wage pressure will result from nominal convergence. In fact, wage increases have already begun to hurt competitiveness. Since 2001, the growth rate of real labour productivity has been lower than the growth rate of real wages (see Figure A1). Therefore, to maintain economic competitiveness and to attain higher living standards, continuation of fast productivity growth is indispensable.

For this study we use a novel firm level dataset from the Estonian Business Registry. This dataset consists of almost all firms that were registered in Estonia over the period 1995-2001 (totalling almost 52 thousand $^{3}$ ). The unique features of this dataset include the absence of any size thresholds, availability of transactions data (e.g. mergers, acquisitions etc.), detailed information on balance sheets, incomes and costs, and it also covers of all economic sectors. Although in most OECD countries the service sector accounts for more than $60 \%$ of valued added and employment (Ahn 2001), partly due to data constraints, most studies on firm demographics and productivity have focused on the manufacturing sector.

The disadvantage of our data is the relatively short time span and the lack of data for the first half of 90's, so we are unable to study firm-level productivity growth during the early transition period (e.g. Brown and Earle (2004) have studied similar issues with data dating back to pre-transition times). Further, our data is at the firm level not the plant level, and we are unable to make distinctions between multi-plant and single-plant firms, as was done, e.g.,

\footnotetext{
${ }^{2}$ See for example Masso et al. (2004), Eamets (2003), Venesaar (2003), Haltiwanger and Vodopivec (2002), Faggio and Konings (1999).

${ }^{3}$ The total number of unique firm ids (registry numbers) in the database is more than 58 thousand, but in fact the total number of firms is approximately 52 thousand because many firms were given registry numbers within the sample period when they were moved from the enterprise registry to the business registry. For more information, see also Ettevõtlus arvudes ... (2002).
} 
by Baldwin and $\mathrm{Gu}$ (2002); that could affect the results if lots of the entry and exit occurs at the plant level rather than at the firm level.

Our empirical analysis utilized the following main steps. Firstly, we investigate the variation of entry and exit of firms in Estonia. Our data show that the enterprise sector in Estonia is characterized by very active entry and exit of firms by international standards. This results from low institutional entry barriers and the emergence of the small and medium sized enterprises sector. Next, we performed survival analysis of newly established firms with the results showing a high survival rate and fast growth of new firms after entry. Finally we calculated decompositions of aggregate (and industry level) productivity changes into components based on productivity growth within continuing firms (firms existing both in the base and reporting period), resource reallocation between continuing firms and the entry and exit of firms. We have found rapid productivity increases during the period under observation.

The paper is structured as follows. In the next section we introduce the data set and methodology used for measurement and decomposition of productivity. In Section 2 we document the basic patterns of firms' entry and exit behaviour and present the firm survival analysis. Section 3 analyses the impact of firm demographics on productivity growth. We decompose total factor productivity to illustrate the importance of net entry and reallocation in explaining total factor productivity growth. The final section concludes.

\section{Data and Measurement Procedure}

\subsection{Description of the Data and Definitions}

The data we use are the company accounts of firms operating in Estonia obtained from the Estonian Business Registry ${ }^{4}$. We have information on almost 52.000 firms operating between 1995 and 2001. However, for each distinct year the number of firms is much smaller due to frequent entry and exit. The number of business entities in Estonia increased over time and,

\footnotetext{
${ }^{4}$ In Estonia, firm level data is essentially gathered and maintained by the Statistical Office of Estonia and the Estonian Business Registry. The Statistical Office of Estonia carries out annual and quarterly surveys, that include all enterprises owned by state and local governments, and all corporate enterprises employing at least 20 employees. For other enterprises owned by Estonian and foreign private entities, a simple random sample is drawn and surveyed. The data set of the Statistical Office includes general firm data and annual reports since 1995. The Estonian Business Registry data set includes annual reports and general firm data for all entities since 1995. The first source of data includes some extra information that could be useful for economic analysis (data on exports, the share of foreign capital, working hours, etc.) However as it is rather hard to access to the database of the Statistical Office, we use the latter source of data.
} 
from 1995-2001, more than tripled: from 12.492 to 38.182 (see Figure A2 in the Appendix). Also, the 1995 and 1996 coverage may be less than perfect ${ }^{5}$ creating potential problems of spurious entry. Another possible problem is spurious exit due to the removal of firms without economic activity from the Business Registry. However, the spurious exit should not affect our results much whereas our entry and exit definitions consider the presence of economic activity in a firm.

Tables A1-A4 in the Appendix document some basic facts about Estonian enterprises between 1995 and 2001. We report changes in the number of firms in different industries over the observed period, their size and the average size in comparison with OECD countries. Estonia has followed a rather radical path of economic reform, and due to this has gone through significant changes in the enterprise sector. Firstly, the emergence of a small and medium sized enterprises sector occurred. In the Soviet economy the industrial structure was dominated by a relatively small number of large establishments, while in market economies small and medium sized enterprises are typically more important. The data set we use for this study is in several aspects more extensive than what has been used in previous studies. It includes small and micro firms and we are able to reliably track firms' exit and entry to measure flows in the dynamic small firm sector.

Over the transition, the relative importance of different sectors has changed. The agricultural sector has contracted as producers lost their markets for agricultural products in the East. At the same time the services sector has expanded, as this sector was underdeveloped in the Soviet economy. During the transition process, important changes in the employment structure have occurred: the share of agriculture has decreased (from 10\% in 1995 to $5 \%$ in 2001 ) and the share of services increased (from $44 \%$ to $49 \%$ ). Though such developments are not unique to Estonia, the decline in the employment share of agriculture and the increase in the employment share of services have been the largest among Central and Eastern European countries during the transition (Eamets 2001).

The Business Registry database includes firms from all economic sectors and contains information about industries (see Tables A2 and A3 in the Appendix regarding the distribution of firms across industries). This enables us to assess how firm dynamics affect productivity changes in the whole economy. Due to data constraints, most studies on firm

\footnotetext{
${ }^{5}$ According to J. Järve from the Estonian Ministry of Economy and Communication, who provided information about the Estonian Business Registry firm level database.
} 
demographics and productivity have focused on the manufacturing sector. From Table A2 we can see that the share of the agricultural sector has declined over time and the share of private services has increased. Table A3 shows the average size of Estonian enterprises (by the number of employees) across different sectors. Average firm sizes in different industries are very close to OECD averages (see Table $\mathrm{A} 4^{6}$ ), however the standard deviation is much smaller due to the small number of very large firms in Estonia. The average firm size increased between 1995 and 1997 but decreased thereafter. This pattern is observable in all sectors.

We also possess information on transactions (mergers, acquisitions, divestitures etc.), which is especially important in a study like ours. Although, the presence of transactions in the data may be important for results (even if there are just a few of them, but these few transactions concern the large firms), it is often not possible to take account of these transactions in empirical studies. Table A5 in the Appendix shows that the most frequent kind of transaction has been a change in the registry code due to the transfer from the Enterprise Registry to the Business Registry ${ }^{7}$. The transactions are more important when weighted by employment (e.g. mergers of large firms). We made the following corrections to the data. In case of "predecessor" enterprises, the observations for old and new registration codes were treated as one firm. For acquisitions, the employment of the acquired firm before the date of the transaction was added to the employment of the acquiring firm. In other cases (mergers, spinoffs, break-ups) we considered the transactions as true entry and exit.

We have also financial reports (balance sheets and profit statements) for almost all firms. The information is detailed (the total number of different items in the annual reports is about 158). Firms are allowed to use two different profit and loss statement forms. In one of them, used by approximately 25 percent of firms, intermediate input costs, employment costs and value added are not available, so productivity calculations (e.g. those using total factor productivity and multi factor productivity) could not be carried out for these firms, and consequently these productivity calculations in our data are made on a smaller sample.

\footnotetext{
${ }^{6}$ As an industry classification, we use the OECD STAN classification (see e.g. Bartelsman and Barnes 2001). It is based on NACE (Statistical Classification of Economic Activities in the European Community) like the Estonian EMTAK code (Classification of Economic Activities of Estonia), so the concordance between the two is straightforward.

${ }^{7}$ The re-registration of enterprises from the Enterprise Registry to the Business Registry and reformation to commercial organizations and self-employed entrepreneurs started in January 1, 1995 following the introduction of the new business code in Estonia. Applications for the re-registration were accepted till September 1, 1997.
} 
In our study we use the following definitions of entry and exit. We assume that a firm is in business if it has either a positive number of employees or positive sales. Secondly, we exclude from the data exit and re-entry after that (the case when firms exit only to re-enter in the future) for the survival analysis ${ }^{8}$. The problem of re-entry was solved in the following way. We interpolated one and two year gaps in the employment and sales variable. When there was a larger gap in the data, we excluded the firm altogether from the sample reducing the size of the sample only by about 40 firms (alternatively, we could have divided such firms into two firms, one before exit and the other one after re-entry; quite probably it would have had only a negligible effect on the final results). Bartelsman et al. (2003) determined entry and exit simply by the occurrence of a business unit in the register. Otherwise, we have used the definitions for entry, exit, one-year firms and continuing firms, as those in Bartelsman et al. (2003): a unit observed as (out, in, in) at $(t-1, t, t+1)$ was an entrant at $t$, a unit observed as (in, in, out) an exit, a unit observed as (out, in, out) as an one year firm and a unit observed as (in, in, in) was a continuing firm.

Survival analysis of entering firms will be performed with the help of survival and hazard functions. The survival function shows the probability that a firm from the given cohort of entrants will have a lifetime longer than the given duration, while the hazard function shows the conditional probability of leaving the market after a certain time. The hazard rate for the cohort $i$ (firms entering in year $i$ ) at duration $j(j \geq i)$ is estimated as the number of firms exiting at time $j$ (denoted by $h_{i j}, h_{i j}=n_{i, k}-n_{i, k+1}$ ) relative to the total number of firms that existed at time $j, n_{i j}$, i.e.

( 1) $\hat{\lambda}_{i j}=\frac{h_{i j}}{n_{i j}}$

Essentially this is the non-parametric Kaplan-Meier approach to survival analysis. Following the definitions, it holds that $0 \leq \lambda_{i j} \leq 1$. In the results' tables we report the simple averages of hazard rates for different cohorts, $\hat{\lambda}_{j}=\sum_{i} \hat{\lambda}_{i j} / N$, where $N$ is the number of cohorts. The estimator for the survivor rate $S_{i j}$ would be then

(2) $S_{i j}=\frac{n_{i, j+1}}{n_{i, j}}=\prod_{k \leq j} \frac{n_{i, k+1}}{n_{i k}}=\prod_{k \leq j} \frac{\left(n_{i k}-h_{i k}\right)}{n_{i k}}=\prod_{k \leq j}\left(1-\lambda_{i k}\right)$

\footnotetext{
${ }^{8}$ If the number of firms of a given cohort $i$ (firms entering at time $i$ ) at time $j$ is $n_{i j}$, then we require that for each $i, n_{i j} \geq n_{i j+t}$ holds for each $t>0$, i.e. the value of $n_{i j}$ is not increasing over the time.
} 
Following the definitions, it holds that for each $j, S_{i j} \geq S_{i j+1}$ and $S_{i i}=1$. The hazard rates derive from the survival function as $\lambda_{i j}=1-S_{i j} / S_{i j-1}$.In the results' tables we report the simple averages of hazard rates for different cohorts, $S_{i}=\sum_{i} S_{i j} / N$. If we denote the probability density function of the firm $i$ lifetime $T$ as $f_{i T}(t)$, then the survival function at duration $\mathrm{t}$ derives also as

(3) $S_{i}(t)=1-\int_{0}^{t_{j}} f_{i T}(t) d t$.

\subsection{Measurement of productivity}

Productivity can be calculated in different ways. Firstly, we calculate it as the real gross output per worker:

(4) $L P Q_{i t}=\frac{Y_{i t}}{L_{i t}} \Rightarrow \log L P Q_{i t}=\log Y_{i t}-\log L_{i t}$,

We measure the labour input $\left(L_{i t}\right)$ as the number of workers (data about working hours is not available in the database). We recognize its possible impact on the results e.g. due to spreading part-time employment. However the threat of overestimating the within-firm effect is small as the share of part-time employment in total employment was, according to Estonian Labour Force Surveys, only $7-9 \%$ in 1995-2001. Real output $\left(Y_{i t}\right)$ is measured as the sum of sales and change in finished goods inventories.

Secondly, we measure productivity as the ratio of value added $\left(V A D D_{i t}\right)$ to the number of workers,

(5) $L P V_{i t}=\frac{V A D D_{i t}}{L_{i t}} \Rightarrow \log L P V_{i t}=\log V A D D_{i t}-\log L_{i t}$,

Although LPV is in some sense a superior measure of labour productivity, for many firms it is not possible to calculate it due to the lack of data. Calculations with both LPQ and LPV are employed to evaluate the robustness of our results, too. Thirdly, productivity could be measured as multifactor productivity (MFP) or total factor productivity (TFP). The index of multifactor productivity is measured as output minus weighted materials, labour and capital input:

( 6) $M F P_{i t}=\frac{Y_{i t}}{K_{i t}^{\alpha_{K}} L_{i t}^{\alpha_{L}} M_{i t}^{\alpha_{M}}} \Rightarrow \log M F P_{i t}=\log Y_{i t}-\alpha_{K} \log K_{i t}-\alpha_{L} \log L_{i t}-\alpha_{M} \log M_{i t}$, 
where $K_{i t}$ is real capital and $M_{i t}$ real materials. The $\alpha$ parameters represent industry cost shares (measured at the level of STAN0 industries ${ }^{9}$ ). The industry capital share is measured as the residual of labour and material cost shares, $\alpha_{K}=1-\alpha_{L}-\alpha_{M}$. The index of total factor productivity will be calculated as value added minus weighted labour and capital input:

(7) $T F P_{i t}=\frac{Y_{i t}}{K_{i t}^{\alpha_{K}} L_{i t}^{\alpha_{L}}} \Rightarrow T F P_{i t}=\log Y_{i t}-\alpha_{K} \log K_{i t}-\alpha_{L} \log L_{i t}$,

where the capital share is calculated as the residual of labour cost share, $\alpha_{K}=1-\alpha_{L}$. The advantage of TFP and MFP over the labour productivity measures is that these consider changes also in production factors other than labour, so that the change in TFP can be attributed to the technological change or improvement in efficiency relative to the best practice technology, while LPV growth is often accompanied by an increase in the capitallabour ratio (often referred to as capital deepening).

We measure capital as the sum of tangible and intangible fixed assets minus goodwill ${ }^{10}$. The following deflators are used to correct for inflation. Output, valued added and intermediate inputs are deflated by respective deflators of the system of national accounts provided by the Statistical Office of Estonia. Capital is deflated with the gross capital formation price index.

\subsection{Productivity decompositions}

We also study how firm demographics is connected to the productivity growth in Estonia. There are a few alternative methodologies for measuring the contribution of firm turnover and production resource reallocation on productivity growth. A good discussion of different methods is presented in Baldwin and $\mathrm{Gu}$ (2002). In the case of Estonia, we would expect high productivity improvements both due to productivity growth within existing firms and due to labour reallocation. Within-firm productivity growth could occur both because of eliminating technical inefficiency (e.g. eliminating the labour hoarding inherited from the Soviet times) and reorganizing work as well as introducing new state-of-the art production technologies. Productivity growth due to reallocation follows from changes in the sectoral structure of

\footnotetext{
${ }^{9}$ STAN0 is the most detailed level in the hierarchy of industry characteristics. There are 43 different industries at STAN0 level. In our data we had firms in 41 STAN0 industries. See also footnote 6.

${ }^{10}$ The value of capital was scaled to the level that given nominal expenditures on capital $\left(Y_{i t}-w_{i t} L_{i t}-p^{M}{ }_{i t} M_{i t}\right.$, $w_{i t}$ is wage and $p_{i t}^{M}$ is the price of intermediate inputs, so $p^{M}{ }_{i t} M_{i t}$ is nominal (inflation unadjusted) material expenditures) the stock level is adjusted to average out to a $5 \%$ return on stock. The scaling is only relevant for
} 
economy and changes in industrial structure connected with the emergence of small and medium sized enterprises.

Productivity at an aggregated (industry) level $P_{t}$, at time $t$, is the weighted average of the productivity of individual businesses (firms, establishments), and thus can be determined as follows (Baldwin and $\mathrm{Gu} 2002)$ :

(8) $P_{t}=\sum_{i} s_{i t} p_{i t}$

where $s_{i t}$ is the employment share of firm $i$ in period $t$ (in the case of total factor productivity and in the case of multifactor productivity, output share is used instead) and $p_{i t}$ is the productivity measure (labour productivity or total factor productivity). According to Foster, Haltiwanger and Krizan (2001, hereafter FHK), using the above formula, changes in productivity can be decomposed as follows:

$$
\begin{aligned}
& \Delta P_{t, t-k}=P_{t}-P_{t-k}=\sum_{i \in C} s_{i t-k} \cdot \Delta p_{i t}+\sum_{i \in C} \Delta s_{i t} \cdot\left(p_{i t-k}-P_{t-k}\right)+\sum_{i \in C} \Delta s_{i t} \cdot \Delta p_{i t}+ \\
& +\sum_{i \in N} s_{i t} \cdot\left(p_{i t}-P_{t-k}\right)-\sum_{i \in X} s_{i t-k} \cdot\left(p_{i t-k}-P_{t-k}\right)
\end{aligned},
$$

where $C, N$ and $X$ describe respectively firms that survive, enter and exit between the dates $t-k$ and $t^{11}$. The three first terms describe the contribution to the productivity growth made by the continuing firms. The first terms, the "within effect" shows the productivity growth within existing enterprises keeping their market shares fixed, that result e.g., from the introduction of new technology or organizational changes, changes in the optimal mix of different production factors, or, in the case of labour productivity changes, in the amount of capital per labour. The second term, the between-firm effect, characterizes productivity growth due to shifts in employment shares (reallocation of labour across different firms). It is positive when market shares increase for continuing firms with higher than average productivity in the base year. The third term is the covariance term that is positive (negative) when market shares and productivity change between $t-k$ and $t$ in the same (different) direction. The entry and exit terms are positive when the entering (exiting) firms have above (below) average base-year productivity. Because of that the FHK method avoids the problem of an earlier decomposition formula proposed by Baily et al. (1992) where the net entry effect could be negative even

comparing productivity levels across countries (with other countries included either in the OECD firm level project or Wold Bank firm level project) and does not affect the within-country comparisons.

${ }^{11}$ Note that the definitions of firm status in this analysis are different from what we used in Section 2.1. An entrant firm is the one observed in $t$, but not in time $t-k$. An exiting firm is observed in time $t$ - $k$, but not in time $t$. Surviving firms are observed both in time $t$ and $t-k$. 
when entrants are more productive than exiters, when the market share of entrants is very low and the market share of exiters is very high ${ }^{12}$.

Griliches and Regev (1992, hereafter GR) proposed a different decomposition, where $t$ and $t$ - $k$ time average values for employment shares and productivities are used:

$$
\begin{aligned}
& \Delta P_{t, t-k}=\sum_{i \in C} \bar{s}_{i} \cdot \Delta p_{i t}+\sum_{i \in C} \Delta s_{i t} \cdot\left(\bar{p}_{i}-\bar{P}\right)+ \\
& +\sum_{i \in N} s_{i t} \cdot\left(p_{i t}-\bar{P}\right)-\sum_{i \in X} s_{i t-k} \cdot\left(p_{i t-k}-\bar{P}\right)
\end{aligned}
$$

The advantage of this approach compared to the decomposition by FHK (2001) is that it is less vulnerable to measurement errors in the employment variable. The latter yield negative covariance between labour productivity and employment shares across firms because an upward bias in employment estimates generates a downward bias in labour productivity estimates. So, the negative covariance term in the FHK method may reflect the spurious correlation between $\Delta s$ and $\Delta p$. Another point is that the FHK method may suffer from "regression to the mean" associated with transitory changes in employment and output. The advantage of the FHK method is that it provides a sharper distinction between the within effect, the between effect and the cross effect.

Baldwin (1995) argues that a drawback of both the FHK and GR methods is that both entering and exiting firms' productivity is compared to the average firm in industry, while, according to the empirics reported by Baldwin (1995), entering firms do not replace incumbent firms but rather exiting firms. So, to properly account for the firm turnover, entering and exiting firms should be compared. This can be done in the spirit of either the FHK or GR method. The first one, denoted as Baldwin $1^{13}$, decomposes aggregate industry productivity as follows:

$$
\begin{aligned}
& \Delta P_{t, t-k}=\sum_{i \in C} s_{i t-k} \Delta p_{i t}+\sum_{i \in C}\left(p_{i t-k}-P_{X t-k}\right) \Delta s_{i t}+\sum_{i \in C} \Delta s_{i t} \Delta p_{i t} \\
& +\sum_{i \in N} s_{i t}\left(p_{i t}-P_{X t-k}\right)
\end{aligned}
$$

where $P_{X t-k}$ is the weighted average productivity of exiting firms in the base year. While the three first terms represent the incumbent firms effect on productivity change (the within-firm effect, between firm effect and a covariance term), the last term can be described as the contribution of firm turnover to aggregate productivity growth.

\footnotetext{
${ }^{12}$ In particular, the formula employed by Baily et al. (1992) was as follows: $\Delta \ln T F P_{t}=\sum_{i \in C} s_{i t-k} \cdot \Delta \ln T F P_{i t}+\sum_{i \in C} \Delta s_{i t} \cdot \ln T F P_{i t}+\sum_{i \in N} s_{i t} \cdot \ln T F P_{i t}+\sum_{i \in X} s_{i t-k} \cdot \ln T F P_{i t-k}$

${ }^{13}$ Consistent with terminology used in Baldwin and Gu (2002).
} 
The second version, labelled as Baldwin 2, replaces the industry average productivity with the exiting firms' average productivity in the GR method:

(12) $\Delta P_{t, t-k}=\sum_{i \in C} \bar{s}_{i} \Delta p_{i t}+\sum_{i \in C}\left(\bar{p}_{i}-P_{X t-k}\right) \Delta s_{i t}+\sum_{i \in N} s_{i t}\left(p_{i t}-P_{X t-k}\right)$,

The three terms measure the contributions due to within-firm productivity growth, betweenfirm compositional shifts and firm turnover.

In addition to these 4 methods, many papers have also exploited the method developed by Olley and Pakes (1996), that involves a cross-sectional decomposition of labour productivity for each industry:

( 13 ) $P_{t}=\bar{p}_{t}+\sum_{i=1}^{N_{t}}\left(s_{i t}-\bar{s}_{t}\right)\left(p_{i t}-\bar{p}_{t}\right)$,

where $\bar{p}_{t}$ and $\bar{s}_{t}$ represent respectively unweighted mean (across firms) productivity and unweighted mean share. The first term is the unweighted average of industry productivity and the second term is the covariance term; the latter is positive if the activity is disproportionately located in high productivity firms; change in the ratio of the gross term to aggregate productivity reflects the extent to which the allocation of activity has become more or less productivity enhancing over time. Changes in the ratio of the covariance term to aggregate productivity reflect the extent to which the allocation of activity has become more or less productivity enhancing (Brown and Earle 2002). Foster et al. (2001) argue that the advantage of this method over FHK is that between-firm differences in productivity are less affected by measurement error and transitory shocks and that the method allows every valid annual observation of a firm to be included.

\section{Basic Patterns of Firm Demographics}

\subsection{The entry and exit of firms}

In a transition economy many new firms are expected to enter (e.g. greenfield firms, spin-offs, foreign entrance, etc), while many existing, especially state-owned enterprises, are forced to leave the market if they fail to restructure. Several studies have found a process of both substantial job creation and destruction in Estonia (see e.g. Masso et al. 2004, Haltiwanger and Vodopivec 2002, Faggio and Konings 1999, etc. among others). Our previous study about gross job flows in Estonia (Masso et al. 2004) found that on average job creation slightly dominates job destruction during the 1995-2001 period. A job reallocation rate of $25 \%$ on average is rather high compared to European market economies, and is similar to the level of 
the United States. The most important aspect of the job flow indicators is that the excess rate is $23 \%$, indicating rather high labour market flexibility in Estonia compared to CEE and western European countries. Compared with studies of western countries, a very high proportion of reallocation is explained by shifts between industries, reflecting rapid changes in economic structure. These high rates indicate that the transition process is not just one in which job destruction takes place, but rather one in which high job creation and destruction occur simultaneously.

The process of firm entry and exit plays an important role in the restructuring process. For example, the entry and exit of firms has been shown to make a significant contribution to sectoral productivity growth in different countries (OECD 2001). This especially applies to the exit of low productivity firms. Indicators of entry and exit of different types of firms in Estonia are presented in Table 1. On average, the annual number of entering firms is about $17 \%$ of the number of existing firms (the entry rate). The annual new exits form about $7 \%$ of the firm total (the exit rate). International evidence has shown that the firm turnover rate (sum of entry and exit rates) amounts to $15-20 \%$ in most countries (Bartelsman et al. 2003). This implies that the Estonian numbers (turnover rate of 24\%) are fairly high by international standards (e.g. even higher than in the U.S.). This is natural during the turbulent transition period with changes in industrial structure (shift from the Soviet large scale production to smaller units and the decline in the relative importance of manufacturing compared to services, where smaller firms dominate). The high entry has been facilitated also by the rather low administrative firm start-up costs in Estonia (Masso et al. 2004). However, firm turnover has, during the sample period, decreased rapidly from $31 \%$ to indicating that these high numbers are peculiar to the transition process and are not sustainable in the long run. The increase in the exit rate since 1998 could be affected by the Russian crisis in the last half of 1998.

[Insert Figure 1 approximately here]

The literature documents that entry and exit involve proportionally low numbers of employees (less than 10\%) in all OECD countries (Bartelsman et al. 2003), because both entering and exiting firms are typically small firms. Annually, the entries and exits involve just $9 \%$ of employees in Estonia (the employment entry and employment exit rates are presented in Table 1). Both entering and exiting firms are relatively small in Estonia, respectively $21 \%$ and 
$45 \%$ of the average incumbent firm. The much smaller size of entrants compared to exits ${ }^{14}$ could reflect downsizing in the business sector due to the transition process. The breakdown by firm size shows that the firm turnover rate declines with the firm's size. We claim that this finding is probably not due to data problems. Due to incomplete registry coverage in 1995 and 1996, we would expect to have a problem of spurious entry rather than spurious exit (see also Section 2.1).

[Insert Table 1 approximately here]

The breakdown by industry shows, that there are higher entry rates in services than in agriculture and manufacturing. The higher entry rates in the services sector are due to the overall expansion in the sector (in services typically small firms dominate). In manufacturing the entry rate is $13 \%$, while the exit rate is $7 \%$. These numbers substantially exceed the annual entry rate $(5.6 \%)$ and exit rate $(3.2 \%)$ of Slovenian manufacturing for the period 1994-2000 (De Loecker and Konings 2003). As De Loecker and Konings argue, the higher entry rates Slovenia were not surprising, as the entry of new firms was an important component of the restructuring and transition process. The overall correlation between entry and exit across industries is positive and significant $\left(0.30^{15}\right)$. Entry and exit occurring simultaneously indicate that entry and exit are two sides of the same process of creative destruction by which new firms replace obsolete firms. In the case of Estonia, these are expected to be respectively new private and foreign firms versus old state-owned firms.

The turnover rate is higher in urban as opposed to rural areas and it is also higher in services as opposed to manufacturing or agriculture. In rural areas low entry together with high exit rates indicate an unfavourable local economic environment.

We can also note that the role of entry and exit is far more important in the private sector than in the state sector. As De Loecker and Konings (2003) argue, this suggests that market forces seem to work better in the private sector than in the state sector, which can also suggest that creative destruction is more important in the private sector than in the state sector. The entry and exit rates in the bottom of Table 1 show that both state and municipal firms have much higher exit than entry rates (as a result, the total number of these firms has declined from 605 to 301). At the same time both domestic private firms and foreign owned firms have an entry

\footnotetext{
${ }^{14}$ We could not see that in any of the 10 OECD countries reviewed in Bartelsman et al. 2003.

${ }^{15}$ The number is the value of the Pearson correlation coefficient between the average (over the years) entry and exit rates (as defined previously) across 41 STAN0 industries.
} 
rate exceeding the exit rate by a factor of about two. Estonia went through relatively fast privatization using mostly sales of assets to strategic investors rather than voucher privatization. The privatization helped to attract foreign direct investments and, for example in 2002, Estonia had the highest stock of inward foreign direct investments as a percentage of GDP among transition economies (UNCTAD 2003). According to Hannula and Tamm (2003), foreign direct investments contributed to the restructuring of manufacturing and the growth in efficiency of individual enterprises. The lower firm turnover rate among foreign owned firms could be also because these firms are on average larger than domestic private firms. The typical story of a successful Estonian enterprise has been that a newly established firm goes first through a period of rapid growth in the domestic market and possibly entry into the export market followed by sale to foreign investors.

\subsection{Firm survival analysis}

The high correlation between entry and exit is not only because entrants induce exits of obsolete firms, but also because many entrants fail to survive infancy. According to OECD data about 20 to $40 \%$ of entering firms fail within two years in OECD countries (Bartelsman et al. 2003). High failure rates for new firms are not necessarily a negative phenomenon, but rather a normal market selection process, by which successful firms are sorted out and survive, while firms with poorer performance and prospects exit. In Estonia both 2-year and 4-year survival rates are higher than in any of the OECD countries reviewed in OECD (2001) (see also Figure 2). The high survival rate could be explained by structural changes, i.e. new firms entering into sectors underdeveloped in the Soviet system could easily find their niche and survive. Similarly to other countries the first years after entry are the most critical for entrants and thereafter the hazard rates (the conditional probability of leaving a market after a certain time) decline (see Table 2). Our results are thus quite different from those observed outside transition by Geroski (1991) who claimed that the consequence of most entry is a temporary displacement of small incumbents and life in the bottom end of the industry size distribution is brutish and short.

[Insert Figure 2 approximately here]

The other important feature of Estonia is the relatively high growth rate of surviving firms during the initial years after entry. This is explained by the high reallocation rate of firms between sectors, i.e. the number of firms in agriculture has dropped from $7.8 \%$ in 1995 to $4.6 \%$ in 2001 , while the number of firms in business services increased from $59 \%$ to $65 \%$ (see 
also Table A2). In expanding industries (like many services industries) it is relatively easy for newcomers to survive due to the less competition from incumbent firms, growing demand etc (e.g. Audtretsch (1995) and Audtretsch and Mahmood (1994) using US data have found a positive effect of industry growth rate on survival probability; Mata and Portugal (1994) found a negative effect of industry growth on survival in Portuguese data). The employment based survival rate (ratio of employment of the given cohort to its initial employment) slopes upward and is flatter because exiting firms are smaller firms and surviving firms grew over time. The employment based survival rates (ratio of employment of the given cohort to its initial employment) at 2 and 4 years is higher than 1 and only below that of the U.S., but above all compared western European countries. Quite the same applies to the net employment gains among surviving firms (Bartelsman et al. 2003). For the U.S., such high rates are explained by intense market experimentation and the large gap between the size of entering and incumbent firms, with firms starting as small and expanding thereafter if successful, caused possibly by a larger market and relatively low entry and exit costs (OECD 2001). In the case of Estonia high post-entry growth could be explained by the competitive advantages of new firms compared to old state-owned firms (higher productivity) and the openness of the economy enabling entry to foreign markets. An Estonian peculiarity is the fact that entrants are relatively small and exit firms are relatively big (see Figure 3). This supports our idea that small firms crowd out big firms ${ }^{16}$.

[Insert Figure 3 approximately here]

In Estonia, firms' survival rates are relatively constant across broad sectors, however the postentry performance of surviving firms differs considerably (see Table 2). Net employment gains are modest in agriculture and public services (firms create about 10\% more jobs over 4 years), while growth is rapid in manufacturing, trade, business services and transport. The high growth in manufacturing could be because, as a tradable goods sector, manufacturing is less constrained by the size of domestic market. The high growth in business services could be because that sector was underdeveloped in Soviet times (Eamets 2001). When splitting the manufacturing industry further into high-tech and low-tech firms ${ }^{17}$, we observe higher net

\footnotetext{
${ }^{16}$ However, especially in the case of Estonia, the small size of entrants and rapid growth thereafter is probably caused also by the lack of resources (capital constraints for small firms, lack of entrepreneurial skills, in some cases also the lack of employees with appropriate skills), i.e. firms start as small even if the entrepreneurs were certain about their competitive advantages in the market.

${ }^{17}$ According to NACE industry classification, the following manufacturing industries could be involved in the high-tech sector: 30, 32, 2423, 353; medium-high sector: 24, 29, 31, 31-35; medium-low sector: 23, 25-28, 3637, 351; low-tech: 15-22, 361 (Männik 2001).
} 
employment gains both among low-tech and high-tech firms, but modest growth among medium firms. For the first group, the explanation could be that these are the foreign firms who have access to foreign markets and have relocated production activities to places like Estonia with access to low cost labour. The high-tech firms were observed to have high postentry growth also in Bartelsman et al. (2003).

[Insert Table 2 approximately here]

\section{The Impact of Firm Demographics on Productivity Growth}

\subsection{Productivity Decompositions at the Aggregate Level}

In this section we study how firm demographics has affected productivity growth in Estonia and try to assess whether, over the observed period, firms have become more efficient. If a process of creative destruction is taking place, we would expect that even as exit takes place, there is simultaneous entry of new and more effective firms. De Loecker and Konings (2003) argue, that if the transition process is indeed characterised by creative destruction, we would expect to find increased total factor productivity in most industries as characterised by high job reallocation. As we have seen, one of the most compelling arguments in favour of high firm turnover is its positive impact on productivity through the entry of new firms using advanced technological and managerial methods and the exit of low productivity units using outdated technologies (Ahn 2001). Productivity growth will contribute to overall economic growth. Table 3 provides some descriptive statistics on the evolution of production costs, productivity and capital deepening in Estonia in broad economic sectors during the sample period. The source of fast labour productivity growth has been to a large extent the investment process and the reduction of labour hoarding. Capital intensity has increased about $75 \%$ in real terms in manufacturing. However, other factors have also played a role as the percentage growth rate of capital intensity is below that of labour productivity (in manufacturing by more than a factor of two). Unit labour costs, measured by combining changes in labour productivity and employee wage costs, show a downward trend, reflecting the decreasing share of labour in production costs due to capital deepening and low wage pressure from trade unions $^{18}$.

\footnotetext{
${ }^{18}$ The union density in Estonia is around 14-15\% (Antila and Ylöstalo 2003).
} 
[Insert Table 3 approximately here]

Let us now turn to the decomposition results. We mostly focus on the GR approach, as the OECD (2001) in its cross-country study chose GR as a reference point. Table 4 presents the results for Estonia in comparison to OECD countries. Firstly, we note that the growth of both labour productivity and total factor productivity has occurred in Estonia at a rather high speed. In fact it has been faster than in any of the countries whose data is available in Barnes et al. $(2001)^{19}$. In manufacturing the proportion of labour productivity growth due to the withinfirm effect is somewhat lower in Estonia relative to the OECD. Under conditions of structural change, this is normal. Our results could reflect that, while in the beginning of transition most efficiency gains could be achieved by reallocation and reorganization, in the later period (that we study) the productivity improvements start to depend more on the adoption of new technologies, investment, etc. Entrants are above average productivity and exiting firms are below average productivity. We argue that effective new private firms replace ineffective old state-owned firms. Entrants often carry new technologies; they are often subsidiaries of foreign companies having better access to marketing channels, financial resources and knowhow (see Djankov and Murrell (2002) for an overview of studies examining how different types of firms have performed during the transition).

[Insert Table 4 approximately here]

The results are mostly presented at 5-year intervals, but we also performed calculations at 3and 2-year intervals. Estonia has been a dynamic economy in the period we study as significant changes have occurred more rapidly than in western economies. The results in Table 5 reveal that the importance of the within-firm effect decreases (increases) with horizon length in the case of labour (total factor) productivity. The entry effect is negative at a lower time horizon, but becomes positive over a longer horizon. The explanation is that initially entrants have lower than average productivity, but their average productivity improves as relatively unproductive firms exit (market selection effect) and surviving firms improve their performance (learning effect).

[Insert Table 5 approximately here]

The decompositions at 3-year intervals over the years 1998-2001 are presented in Table 6 . One possible hypothesis is that the importance of reallocation in productivity growth might 
decrease over time as the transition process approaches its end. Though the table indeed shows the reduction of the net entry effect over the time, we cannot rule out here the impact of aforementioned data problems, i.e. incomplete coverage in the first 2 years of the sample.

[Insert Table 6 approximately here]

Productivity growth has been positive also in the services sector in Estonia, and here the net entry effect is also rather important (accounting for 35\% of productivity growth). Total factor productivity growth has also been rather fast in Estonian manufacturing, and in line with earlier literature in this field. Reallocation plays a larger role here than in labour productivity change (only $51 \%$ is due to the within-firm effect), so it's is more important than in OECD countries. The difference could be because in the OECD much of labour productivity improvement is due to changes in capital intensity (OECD 2001), while other factors are more important in Estonia (increase in the efficiency of labour usage, reduction of labour hoarding, organizational changes, etc).

We can conclude from the above numbers that in Estonia the destruction has been creative, the large firm turnover has contributed to the productivity growth and the transition is succeeding. We find that to be an important result. A different example among emerging economies is Israel, where Griliches and Regev (1992) found that despite of the large firms and jobs turnover most of the productivity growth occurred within firms, with mobility accounting only for a small fraction; similar evidence has been was found also for Chile and Colombia (Roberts and Tybout 1997). So, concerning emerging market economies Estonia looks here more similar to Taiwan, where the contribution of net entry accounted for almost $50 \%$ of productivity growth (Aw et al. 1997). A similar feature of both Taiwan and Estonia is the low start-up costs that speed firm turnover and increase pressure for inefficient firms to exit (Aw et al. 1997).

\subsection{The productivity decomposition results for individual industries}

Figure 4 and Table 7 reveal the results for individual industries (for more detailed results, see also Table A6 and Table A7in the Appendix). Labour productivity growth has been positive and large in all industries, while total factor productivity growth has been largest in agriculture, manufacturing and construction, and lower in services. The impact of both net entry and between effects on TFP growth are higher in agriculture and services, the reason

\footnotetext{
${ }^{19}$ We mostly concentrate the comparisons to this source as it has used similar methodology.
} 
probably being that these sectors are the ones having respectively contracted and expanded a lot while the share of manufacturing has been more stable. In labour productivity growth the differences are not that profound. Table A7 shows that the results are mostly robust to the method of decomposition, although less so in services industries.

Table 7 reveals that in most industries, entering firms have above and exiting firms below average productivity. Generally, among the 41 industries the number of industries experiencing a positive contribution due to exiting and entering firms is respectively 85 and $65 \%$. The high average productivity of entrants for some countries is considered as evidence of entry barriers, whereby only those potential entrants who are sure about their success enter. To our understanding this is not the case in Estonia given the observed high entry and exit rates and low entry barriers.

[Insert Figure 4 approximately here]

While exiting firms' productivity growth is relatively stable across industries (with an average of $64 \%$ ), the entrants' relative productivity varies from $102 \%$ (in agriculture) to $-2 \%$ (transport), indicating the differing importance of reallocation across industries. The employment-weighted share of entries and exits is much higher than in Baldwin and $\mathrm{Gu}$ (2002), indicating again the considerable size of reallocation in the Estonian economy.

[Insert Table 7 approximately here]

\subsection{Productivity decompositions among foreign owned versus domestic firms}

In this section we present productivity decompositions where firms are divided into domestic and foreign owned (for other countries, similar calculations have been made by Baldwin and $\mathrm{Gu}, 2002)^{20}$. Economic theory offers several arguments for the positive impacts of foreign direct investment. Foreign firms have a positive own-firm effect on productivity, e.g. due to their better access both to state-of-the-art technologies, their superior production equipment, managerial know-how, better access to patents, licenses and capital resources (Aitken and Harrison 1999). On the other hand, they have positive technology spill-overs to domestic firms if they cannot internalize the full value of the benefits associated with their presence, in which case some of it "spills over" to local firms (Blomström and Kokko 1996). These spillovers could be in the form of transfer of know-how and technologies, increased competition 
between enterprises, worker mobility and supplier upgrading (Aitken and Harrison 1999). Djankov and Murrell (2002) reviewed a large number of studies on enterprise restructuring in transition countries, and concluded, that privatization to foreign owners had a large positive effect on enterprise performance. Männik (2001) analyzed the results of the survey "Foreign investor" 1996-1999 and showed that the technological level of foreign owned enterprises in Estonia had risen thanks to the transfer of specific technology and skills from the parent enterprise.

Table 8 reports the shares of domestic and foreign entrants, exits and incumbents. First, although the employment share of foreign firms is larger than their share in the total number of firms both among entering, exiting and continuing firms, reflecting they are larger than domestic firms, we see that while continuing foreign firms are much bigger than domestic firms, then entering are only somewhat bigger and the exiting are roughly of the same size. Foreign-controlled continuing firms have approximately $90 \%$ higher labour productivity than domestic firms. Among entering firms (as well as among exiting firms), the difference is only about $60 \%$.

[Insert Table 8 approximately here]

Table 9 shows that the contribution of foreign owned firms to labour productivity growth is comparable to their share in employment, while it is relatively more important for the growth of total factor productivity growth (respectively $23 \%(42 \%)$ of labour (total factor) productivity growth comes from foreign firms). One reason is probably the fast capital deepening among domestically owned companies in recent years. We argue that part of the story could be the improving availability of external financing for domestic firms. In the first half of the 1990s it was extremely difficult for Estonian firms to obtain bank loans, while foreign owned firms could obtain financing from their parent companies (in the case of subsidiaries and daughter companies) or from foreign banks. By now, financing possibilities have become more equal. The loosening of liquidity constraints and the resulting capital deepening in domestic firms is a potentially important factor affecting productivity growth ${ }^{21}$. We note that the total effect of FDI on productivity could be different from the numbers

\footnotetext{
${ }^{20}$ For a comprehensive overview of the role of foreign direct investments in the Estonian economy, please see Varblane (2001).

${ }^{21}$ The different access to financing among foreign owned and domestic firms in Estonia is analyzed by Mickiewicz et al. (2004).
} 
reported here as these numbers do not capture possible spill-over effects from foreign to domestic firms.

The contribution of factor reallocation to productivity growth is generally more important among domestic firms. One reason is that foreign exits' productivity is higher than that of their domestic counterparts, reducing the negative effect of net entry. The contribution of foreign entry to productivity growth could have occurred already in the first half of 90's; unfortunately we are unable to study that with our data.

[Insert Table 9 approximately here]

\section{Conclusions}

Our main conclusions are as follows. Entry and exit rates are fairly high by international standards, but declining over the period considered. Both entrants and exiting firms are small compared to incumbent firms, but entrants are much smaller than exiting firms leading to overall smaller units. Both entering and exiting firms are smaller than incumbent firms (as is usually found), but exiting firms are much larger than entering firms. This is a phenomenon, which likely reflects changes in the industrial structure. Survival rates for new firms are rather high and surviving firms grow relatively fast. This could be explained by structural changes and openness of the economy, i.e. firms entering the previously underdeveloped sectors find it easy to stay in the market.

Both labour and total factor productivity growth has been rather fast in Estonia. In manufacturing, the proportion of within-firm labour productivity (total factor productivity) growth is somewhat lower (higher) in Estonia relative to OECD countries. The entrants (exiting firms) are generally above (below) average productivity levels of incumbent firms. The impact of both net entry and between effects in TFP growth are higher in agriculture and services probably because these sectors are the ones that have respectively contracted and expanded while manufacturing has been more stable. Also capital intensity has increased significantly in agriculture.

The general finding of our paper is that the entry and exit of firms is good for productivity improvement and economic growth. If we discuss potential policy implications connected with that finding, then in our opinion Estonia should definitely continue with the "firmfriendly" policy approach what we have today. Barriers to market entry are relatively low, and 
our labour market continues to be flexible. Also policies aimed at encouraging firms to engage in restructuring are likely to have a substantial impact on aggregate productivity growth. These are also very important from an employment policy point of view and help to reduce unemployment. From our study and also from earlier studies made about the Estonian labour market, we can conclude that labour reallocation between sectors were, to a large extent, completed by 2000-2001. We can see from employment trends that the labour market has stabilised. Under such conditions, the entry of new firms will become the most important source of job creation and provide the greatest potential for unemployment reduction.

Of course, the analysis presented in this paper has not covered all aspects nor exploited all possible modelling approaches, so the study can be extended in several directions. A regression analysis of firm dynamics could complement the indicators calculated in this paper, e.g. exit regressions (probit and logit models), survival regressions (duration models) and growth regressions for continuing firms'. 


\section{References}

Aghion, P. and P. Howitt (1992), "Model of growth through creative destruction", Econometrica, Vol. 60, No. 2, pp. 323-351.

Ahn, S. (2001), "Firm dynamics and productivity growth: a review of micro evidence from OECD countries", OECD Economics Department Working Paper No. 297, Paris

Aitken, B. J. and A. E. Harrison (1999), "Do Domestic Firms Benefit from Direct Foreign Investment? Evidence from Venezuela", The American Economic Review, Vol. 89, No 3, pp. 605-618.

Antila, J. and P. Ylöstalo, (2003), "Working Life Barometer in the Baltic Countries 2002", Ministry of Labour Finland, Labour Policy Studies No 247, 325 pp.

Audretsch, D. and T. Mahmood (1994), "The Rate of Hazard Confronting New Firms and Plants in US Manufacturing", Review of Industrial Organization, Vol. 9, pp. 41-56.

Audretsch, D.B. (1995), "Innovation, survival and growth", International Journal of Industrial Organization, 13, pp. 441-457.

Aw, B. Y., Chen, X. and M. J. Roberts (1997), "Firm-level evidence on productivity differentials, turnover, and exports in Taiwanese Manufacturing", NBER Working Paper No 6235, $52 \mathrm{pp}$.

Baldwin, J. R. (1995), “The Dynamics of Industrial Competition”. New York, Cambridge University Press.

Baily, M., Hulten, C. and D. Campbell (1992), "Productivity dynamics in manufacturing plants", Brookings Papers on Economic Activity: Microeconomics 2, pp. 187-249.

Baldwin, J. R. and W. Gu (2002), "Plant Turnover and Productivity Growth in Canadian Manufacturing", OECD STI Working Papers 2002/2, 50pp.

Bartelsman, E. and M. Barnes (2001), "Comparative Analysis of Firm Level Data: A Low Marginal Cost Approach", OECD DSTI/EAS/IND/SWP/AH(2001)

Bartelsman, E., Scarpetta, S. and F. Schivardi (2003), "Comparative Analysis of Firm Demographics and Survival: Micro-Level Evidence for the OECD countries", OECD Economics Department Working Paper No. 348, 59 pp.

Blomström, M. and A. Kokko (2003), “A. Human Capital and Inward FDI”, SSE Working paper No 167, 25 p.

Brown, J.D. and J. S. Earle (2002), "Economic Reforms and Productivity-Enhancing Reallocation in the Post-Soviet Transition", IZA Discussion Paper No 1044, 49 pp.

Brown, J.D. and J. S. Earle (2002), "Job Reallocation and Productivity Growth Under Alternative Economic Systems and Policies: Evidence from the Soviet Transition", IZA Discussion Paper No 644, 52 pp.

Clare, R. and A. Paternoster (2002), "Labour Costs Survey 2000: Candidate Countries", Statistics in Focus, Population and Social Conditions, Theme 3, 23/2002, Eurostat.

De Loecker, J. and J. Konings (2003),"Creative Destruction and Productivity Growth in an Emerging Economy: Evidence from Slovenian Manufacturing", IZA Discussion Paper No 971, 39 pp. 
Djankov S. and P. Murrell (2002), "Enterprise Restructuring in Transition: A Quantitative Survey”, Journal of Economic Literature 40, 739-792.

Eamets, R. (2001), "Reallocation of Labour during Transition. Disequlilibrium and Policy Issues. The Case of Estonia", Dissertationes Rerum Oeconomicarum Universitatis Tartuensis, No 5, Tartu University Press.

Eamets, R. (2003), "Tööturuliikumiste analüüs piirkonniti”, in H. Kaldaru (Ed.), Eesti Regionaalarengu sotsiaalmajanduslik käsitlus, 1k. 183-235. Tartu: Tartu Ülikooli Kirjastus

Ericson, R. and A. Pakes (1995), "Markov perfect industry dynamics: a framework for empirical analysis", Review of Economic Studies, Vol. 63, No. 1, pp. 53-82.

Ettevõtlus arvudes 1999-2001 (2002). Tallinn: Justiitsministeeriumi registrikeskus, 85 pp.

EUROSTAT (2001) Statistics in Focus, 2 No 13/2001: Valued added, employment, remuneration and labour productivity in the candidate countries.

Faggio, G. and Konings, J. (1999), "Gross Job Flows and Firm Growth in Transition Countries: Evidence from Firm Level Data on Five Countries", CEPR Discussion Paper No. 2261. Published as: Faggio, G. and J. Konings (2003), "Job creation, job destruction and employment growth in transition countries in the 90s", Economic Systems, Vol. 27, pp. 129154.

Foster, L., Haltiwanger, J. and C. Krizan (2001), "Aggregate Productivity Growth: Lessons from the Microeconomic Evidence", In New Developments in Productivity Analysis. Edward Dean, Michael Harper and Charles Hulten (eds.) Chicago: Chicago University Press, pp 303372.

Geroski, P. A. (1991), Market Dynamics and Entry, Oxford: Basil Blackwell

Griliches, Z. and H. Regev (1992), "Productivity and Firm Turnover in Israeli Industry 197988", NBER Working Paper No 4059

Haltiwanger, J. C. and M. Vodopivec (2002), "Gross worker and job flows in a transition economy: an analysis of Estonia", Labour Economics, Vol. 9, pp. 601-630.

Hamermesh D. S. (1993), Labour Demand, New Jersey: Princeton University Press.

Hannula H. and K. Tamm (2003), "Restructuring and Efficiency in the Estonian Manufacturing Industry: the Role of Foreign Ownership", FEBA Working Paper No.15, University of Tartu.

Jovanovic, B. (1982), "Selection and the Evolution of an Industry", Econometrica, Vol. 50, pp. 649-670.

Männik, K. (2001), „The Role of Foreign Direct Investments in Technology Transfer to Estonia", in U. Varblane (Ed.) Foreign Direct Investments in the Estonian Economy, pp. 175268. Tartu: Tartu Ülikooli Kirjastus

Masso, J., Eamets, R., and K. Philips (2004), "Job creation and job destruction in Estonia: labour reallocation and structural changes", unpublished manuscript, Tartu, University of Tartu.

Mata, J. and P. Portugal (1994), "Life duration of new firms", Journal of Industrial Economics, Vol. 42(3), September, pp. 227-245.

Mickiewicz, T., Bishop, K. and U. Varblane (2004), "Financial Constraints in Investment Foreign Versus Domestic Firms. Panel Data Results From Estonia, 1995-1999”, William 
Davidson Institute Working Paper No. 649, Ann Arbor, MI: University of Michigan Business School.

OECD, 2001. Economic Outlook. Paris.

Olley, G. T. and A. Pakes (1996), "The dynamics of productivity in the telecommunications equipment industry”, Econometrica, Vol. 64, Issue 6, pp. 1263-1297.

Orazem, P.F. and M. Vodopivec (2002), "Do Market Pressures Induce Economic Efficiency: The Case of Slovenian Manufacturing, 1994-2001", IZA Discussion Paper No 901, 39 pp.

Roberts, M.J. and J. R. Tybout (1997), "Producer turnover and productivity growth in developing countries", The World Bank Research Observer, Vol. 12, no. 1, pp. 1-18

UNCTAD (2003), World Investment Report 2003, FDI Policies for Development: National and International Perspectives, UN, New York and Geneva.

Varblane, U. (Ed.) (2001), "Foreign Direct Investments in the Estonian Economy", Tartu, Tartu University Press, 336 pp.

Venesaar, U. (2003), “Töökohtade loomine ja kaotamine Eesti ettevõtetes”, In Ettevõttemajandus Eestis ja Euroopa Liit, Mattimar, Tallinn, Pärnu, pp. 236-244.

Warzynski, F. (2002), "Do Schumpeterian Waves of Creative Destruction Lead to Higher Productivity? Panel Data Evidence from Poland", LICOS Discussion Paper 120/2002, 20 pp. 


\section{Figures and tables}

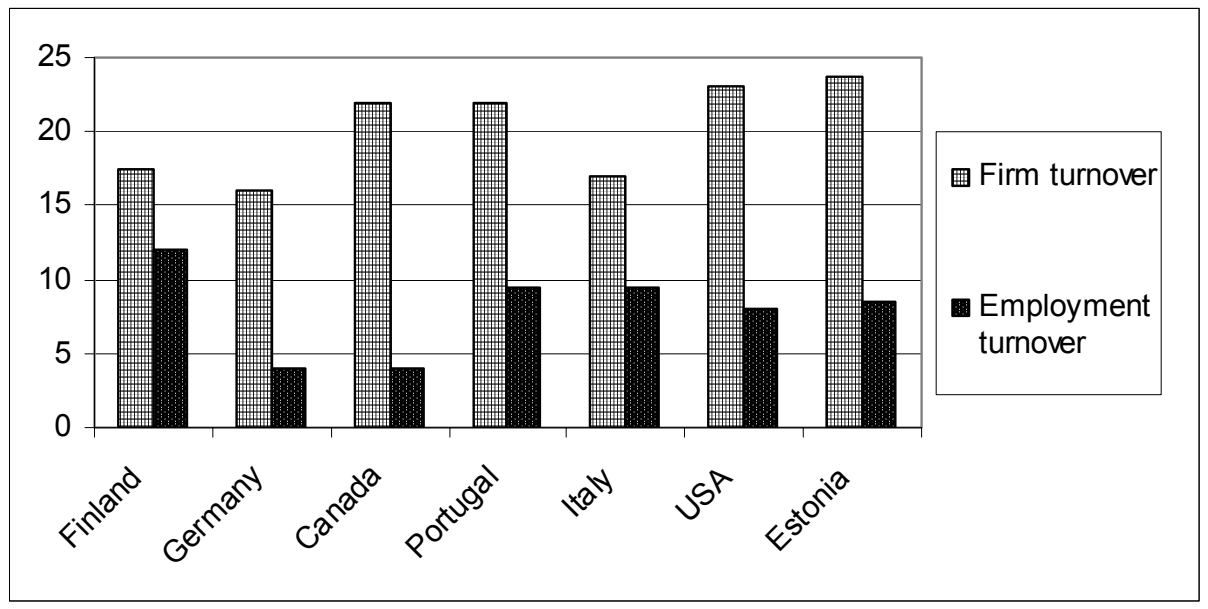

Figure 1. Firm and employment turnover in Estonia compared with western countries

Source: Estonia - Estonian Business Registry database, authors' calculations; other countries - Bartelsman et al. 2003.

Note. For Estonia the numbers are the averages of 1995-2001; for other countries 1989-1994
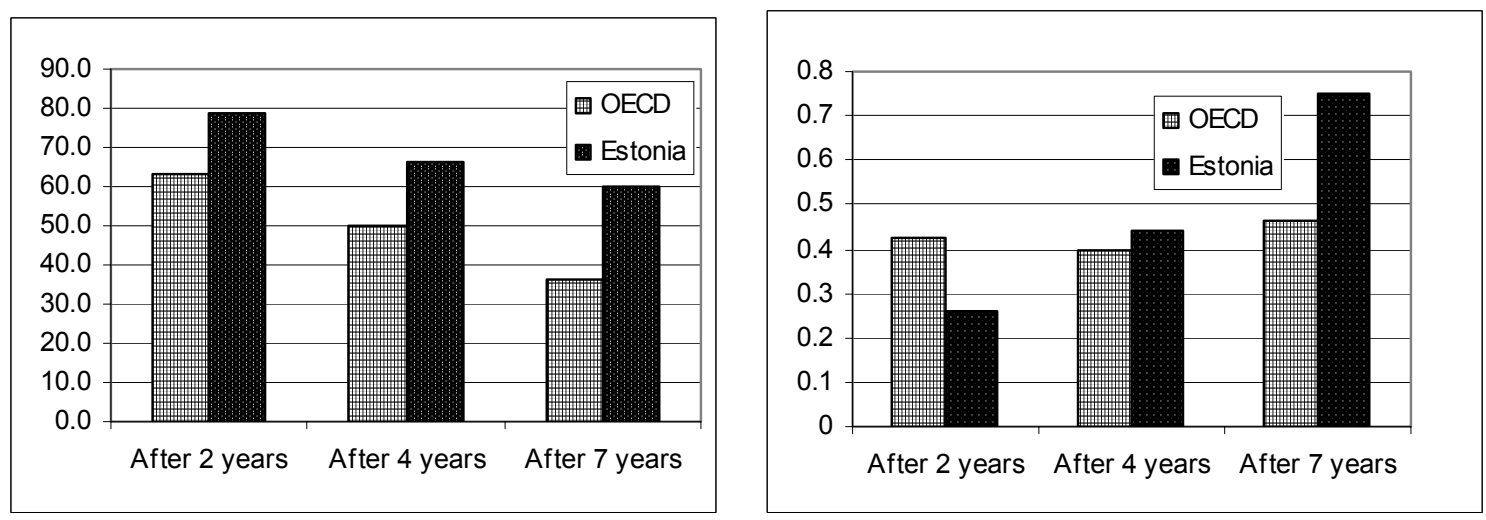

Figure 2. Firm survival rates (left panel) and net employment gains (right panel) in Estonia compared with western countries at different lifetimes.

Source: Estonia - Estonian Business Registry database, authors' calculations; other countries - Bartelsman et al. 2003.

Note. For Estonia, due to the short sample the rates have been calculated at 2, 4 and 6 years. 


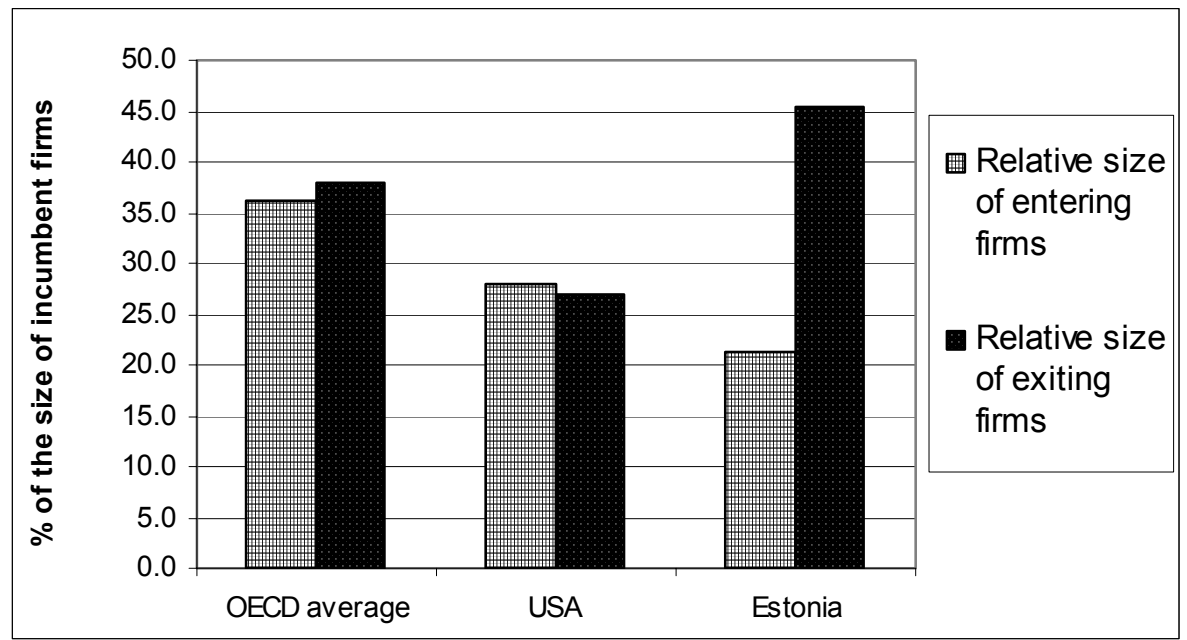

\section{Figure 3. The relative size of entrants in Estonia compared with western countries}

Source: Estonia - Estonian Business Registry database, authors' calculations; other countries - Bartelsman et al. 2003.

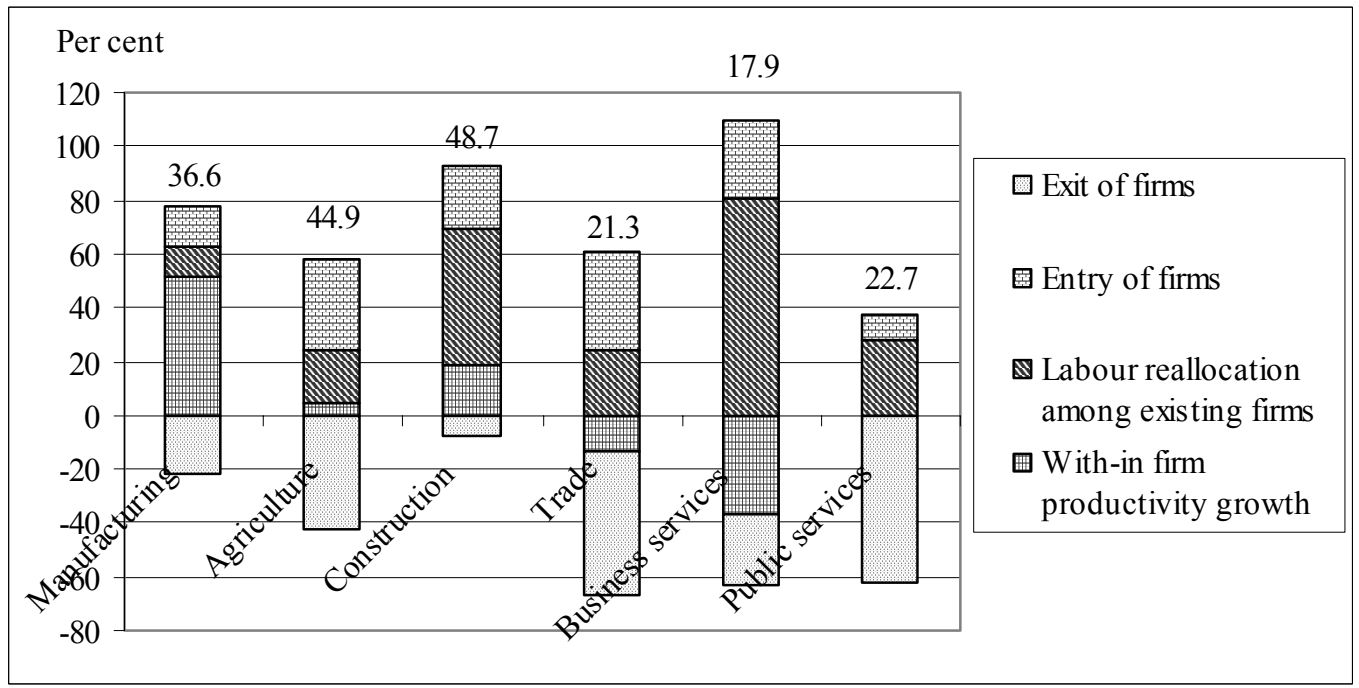

Figure 4. Decompositions of total factor productivity growth in different industries

Source: Estonia - Estonian Business Registry database, authors' calculations

Note. Figures above the columns are the percentage overall productivity growth. Decompositions are based on Griliches-Regev method over the 5-year interval. 
Table 1. Firm entry and exit rates by employer characteristics in Estonia

\begin{tabular}{|c|c|c|c|c|c|c|}
\hline & $\begin{array}{l}\text { Entry } \\
\text { rate }^{\mathrm{a}}\end{array}$ & Exit rate & $\begin{array}{l}\text { Turnover } \\
\text { rate }\end{array}$ & $\begin{array}{l}\text { Employment } \\
\text { entry rate }\end{array}$ & $\begin{array}{l}\text { Employment } \\
\text { exit rate }\end{array}$ & $\begin{array}{l}\text { Employment } \\
\text { turnover rate }\end{array}$ \\
\hline \multicolumn{7}{|l|}{ Year } \\
\hline 1996 & 0.20 & 0.11 & 0.31 & 0.04 & 0.06 & 0.10 \\
\hline 1997 & 0.20 & 0.05 & 0.25 & 0.06 & 0.03 & 0.09 \\
\hline 1998 & 0.17 & 0.06 & 0.23 & 0.04 & 0.04 & 0.09 \\
\hline 1999 & 0.15 & 0.07 & 0.22 & 0.04 & 0.03 & 0.07 \\
\hline 2000 & 0.10 & 0.07 & 0.18 & 0.03 & 0.04 & 0.08 \\
\hline \multicolumn{7}{|l|}{ Size class } \\
\hline 0 & 0.20 & 0.07 & 0.26 & 0.00 & 0.00 & 0.00 \\
\hline $1-9$ & 0.09 & 0.05 & 0.14 & 0.11 & 0.06 & 0.17 \\
\hline $10-19$ & 0.04 & 0.04 & 0.08 & 0.06 & 0.05 & 0.11 \\
\hline $20-49$ & 0.03 & 0.03 & 0.06 & 0.04 & 0.05 & 0.08 \\
\hline $50-99$ & 0.02 & 0.03 & 0.06 & 0.03 & 0.05 & 0.07 \\
\hline $100-249$ & 0.02 & 0.03 & 0.04 & 0.03 & 0.03 & 0.06 \\
\hline $250-499$ & 0.03 & 0.03 & 0.06 & 0.04 & 0.04 & 0.08 \\
\hline More than 500 & 0.02 & 0.02 & 0.04 & 0.03 & 0.03 & 0.05 \\
\hline \multicolumn{7}{|l|}{ Sector } \\
\hline Agriculture & 0.12 & 0.08 & 0.20 & 0.03 & 0.06 & 0.09 \\
\hline Manufacturing & 0.13 & 0.07 & 0.20 & 0.04 & 0.04 & 0.07 \\
\hline Construction & 0.14 & 0.07 & 0.22 & 0.05 & 0.05 & 0.10 \\
\hline Trade & 0.17 & 0.08 & 0.25 & 0.05 & 0.05 & 0.11 \\
\hline Business services & 0.18 & 0.07 & 0.25 & 0.05 & 0.05 & 0.10 \\
\hline Transport & 0.18 & 0.06 & 0.24 & 0.03 & 0.03 & 0.06 \\
\hline Public services & 0.19 & 0.06 & 0.25 & 0.07 & 0.03 & 0.10 \\
\hline \multicolumn{7}{|c|}{ Location (size of population in establishment) } \\
\hline$>500$ 000: Tallinn & 0.18 & 0.07 & 0.25 & 0.04 & 0.04 & 0.08 \\
\hline 100 000-500 000:Tartu & 0.20 & 0.06 & 0.26 & 0.05 & 0.04 & 0.09 \\
\hline Large towns: $50000-99000$ & 0.18 & 0.08 & 0.25 & 0.05 & 0.06 & 0.11 \\
\hline $\begin{array}{l}\text { Other: small towns and rural } \\
\text { areas }\end{array}$ & 0.13 & 0.08 & 0.21 & 0.05 & 0.05 & 0.10 \\
\hline \multicolumn{7}{|l|}{ Ownership type } \\
\hline State firms & 0.02 & 0.12 & 0.13 & 0.04 & 0.04 & 0.08 \\
\hline Municipal firms & 0.03 & 0.07 & 0.10 & 0.01 & 0.04 & 0.05 \\
\hline Domestic private firms & 0.12 & 0.05 & 0.17 & 0.05 & 0.04 & 0.09 \\
\hline Foreign firms & 0.08 & 0.04 & 0.12 & 0.03 & 0.02 & 0.05 \\
\hline The total economy ${ }^{\text {c) }}$ & 0.17 & 0.09 & 0.24 & 0.04 & 0.04 & 0.09 \\
\hline
\end{tabular}

Source: Estonian Business Registry database, authors' calculations

a) Entry (exit) rate is the ratio of the number of entering (exiting) firms to the number of existing firms. The turnover rate is the sum of the two rates.

b) Employment entry (exit) rate is the ratio of the sum of jobs in entering (exiting) firms to the sum of jobs in existing firms. The employment turnover rate is the sum of the two rates.

c) Figures for the total economy refer to averages over the period 1996-2000. 
Table 2. Survival analysis of Estonian firms across industries

\begin{tabular}{|c|c|c|c|c|c|}
\hline $\begin{array}{c}\text { Year after } \\
\text { entry }\end{array}$ & Industry & $\begin{array}{c}\text { Hazard } \\
\text { rate }^{\text {a) }}\end{array}$ & $\begin{array}{c}\text { Survivor rate } \\
\text { b) }\end{array}$ & $\begin{array}{c}\text { Employment based } \\
\text { survivor rate }\end{array}$ & $\begin{array}{l}\text { Net employment } \\
\text { gains among } \\
\text { surviving firm }\end{array}$ \\
\hline 2 & Agriculture & 7.16 & 82.8 & 1.18 & 17.5 \\
\hline 4 & Agriculture & 10.95 & 64.6 & 1.04 & 12.4 \\
\hline 2 & Manufacturing & 8.91 & 79.4 & 1.32 & 21.1 \\
\hline 4 & Manufacturing & 4.76 & 66.0 & 1.84 & 60.1 \\
\hline 2 & Low-tech manufacturing & 6.1 & 30.9 & 2.19 & 75.5 \\
\hline 4 & Low-tech manufacturing & 8.9 & 77.7 & 1.44 & 22.9 \\
\hline 2 & Medium low tech manufacturing & 1.65 & 36.0 & 1.65 & 52.4 \\
\hline 4 & Medium low tech manufacturing & 9.83 & 80.2 & 1.21 & 19.2 \\
\hline 2 & Medium high tech manufacturing & 6.01 & 94.0 & 1.20 & 10.3 \\
\hline 4 & Medium high tech manufacturing & 3.9 & 42.1 & 1.34 & 38.0 \\
\hline 2 & High-tech manufacturing & 5.21 & 86.6 & 2.19 & 73.6 \\
\hline 4 & High-tech manufacturing & 6.25 & 69.8 & 3.34 & 264.7 \\
\hline 2 & Construction & 9.76 & 80.9 & 1.32 & 26.7 \\
\hline 4 & Construction & 7.43 & 67.4 & 1.49 & 34.0 \\
\hline 2 & Business services & 10.02 & 77.9 & 1.43 & 33.1 \\
\hline 4 & Business services & 7.07 & 65.8 & 1.61 & 56.5 \\
\hline 2 & Transport & 11.24 & 75.9 & 1.52 & 36.5 \\
\hline 4 & Transport & 8.08 & 62.8 & 1.65 & 55.0 \\
\hline 2 & Wholesale and retail trade & 7.82 & 82.6 & 1.51 & 29.5 \\
\hline 4 & Wholesale and retail trade & 6.14 & 72.1 & 1.75 & 82.9 \\
\hline 2 & Public services & 7.69 & 69.5 & 1.09 & 11.9 \\
\hline 4 & Public services & 7.56 & 83.9 & 1.11 & 17.2 \\
\hline 2 & The total economy & 9.69 & 78.7 & 1.32 & 25.9 \\
\hline 4 & The total economy & 7.03 & 66.1 & 1.49 & 44.1 \\
\hline
\end{tabular}

Source: Estonian Business Registry database, authors' calculations

a) The hazard rate shows the conditional probability of leaving market after a certain time

b) The survivor rate at duration $\mathrm{j}$ shows the probability that a firm from the given cohort of entrants will have a lifetime longer than the duration $\mathrm{j}$.

c) The survivor rate at duration $\mathrm{j}$ shows the ratio of the cohorts' employment at age $\mathrm{j}$ over the cohort's initial employment.

d) Net employment gains at the lifetime $\mathrm{j}$ is calculated as the percentage increase in employment of surviving firms with respect to their initial employment

Figures refer to average rates estimated for different cohorts of firms that entered the market from 1996 till 2000 . 
Table 3. Evolution of components of production costs, productivity and capital intensity in Estonia

\begin{tabular}{|c|c|c|c|c|c|}
\hline Industry & $\begin{array}{c}\text { Capital intensity } \\
\text { ('000 euro) }\end{array}$ & $\begin{array}{c}\text { Labour productivity } \\
\text { ('000 euro) }\end{array}$ & $\begin{array}{c}\text { Unit labour } \\
\text { costs }\end{array}$ & $\begin{array}{c}\text { Share of labour in } \\
\text { value added }\end{array}$ & $\begin{array}{c}\text { Ratio of material } \\
\text { costs to sales }\end{array}$ \\
\hline \multicolumn{6}{|l|}{ Primary sector } \\
\hline 1995 & 1.63 & 3.41 & 0.290 & 0.6 & 0.56 \\
\hline 1996 & 1.59 & 3.99 & 0.260 & 0.58 & 0.54 \\
\hline 1997 & 1.88 & 5.12 & 0.230 & 0.52 & 0.56 \\
\hline 1998 & 3.27 & 3.55 & 0.320 & 0.64 & 0.62 \\
\hline 1999 & 2.64 & 4.97 & 0.240 & 0.43 & 0.66 \\
\hline 2000 & 2.76 & 7.25 & 0.160 & 0.38 & 0.58 \\
\hline 2001 & 3.38 & 8.82 & 0.150 & 0.35 & 0.57 \\
\hline \multicolumn{6}{|l|}{ Manufacturing } \\
\hline 1995 & 0.84 & 5.59 & 0.230 & 0.5 & 0.53 \\
\hline 1996 & 1.03 & 6.95 & 0.210 & 0.47 & 0.55 \\
\hline 1997 & 1.25 & 8.77 & 0.200 & 0.46 & 0.56 \\
\hline 1998 & 1.47 & 10.15 & 0.180 & 0.45 & 0.56 \\
\hline 1999 & 1.45 & 10.27 & 0.190 & 0.45 & 0.56 \\
\hline 2000 & 1.47 & 11.09 & 0.170 & 0.43 & 0.54 \\
\hline 2001 & 1.48 & 11.80 & 0.180 & 0.44 & 0.54 \\
\hline \multicolumn{6}{|l|}{ Services } \\
\hline 1995 & 0.64 & 8.01 & 0.120 & 0.37 & 0.7 \\
\hline 1996 & 0.85 & 9.98 & 0.110 & 0.35 & 0.69 \\
\hline 1997 & 1.16 & 12.87 & 0.100 & 0.33 & 0.7 \\
\hline 1998 & 1.23 & 12.71 & 0.100 & 0.33 & 0.68 \\
\hline 1999 & 1.30 & 12.45 & 0.110 & 0.34 & 0.66 \\
\hline 2000 & 1.34 & 12.49 & 0.110 & 0.33 & 0.64 \\
\hline 2001 & 1.37 & 12.49 & 0.110 & 0.34 & 0.63 \\
\hline
\end{tabular}

Source: Estonian Business Registry database, authors' calculations

Note. Capital intensity is measured as the amount of capital per employee. Labour productivity is calculated as the ratio of sales to the number of employees. Unit labour cost is calculated as the ratio of wage to labour productivity. Value added is calculated as sales minus intermediate input costs.

Table 4. Comparison of productivity decompositions in Estonia and OECD countries

\begin{tabular}{|c|c|c|c|c|c|c|}
\hline & $\begin{array}{l}\text { Productivity } \\
\text { growth }\end{array}$ & Within & Between & Net entry & Entry & Exit \\
\hline & \multicolumn{6}{|c|}{ Labour productivity growth } \\
\hline \multicolumn{7}{|l|}{ Manufacturing } \\
\hline OECD average & 15.3 & 67.7 & 7.6 & 24.6 & -4.1 & -28.7 \\
\hline Estonia & 46.7 & 59.2 & -2.0 & 42.8 & 5.7 & -37.1 \\
\hline \multicolumn{7}{|l|}{ Services } \\
\hline OECD average & -7.0 & 16.8 & -366.3 & 449.5 & 141.3 & -308.3 \\
\hline \multirow[t]{2}{*}{ Estonia } & 27.6 & 63.9 & 1.2 & 34.9 & 1.3 & -33.6 \\
\hline & \multicolumn{6}{|c|}{ Total factor productivity growth } \\
\hline \multicolumn{7}{|l|}{ Manufacturing } \\
\hline OECD average & 9.9 & 44.2 & 11.2 & 44.8 & 12.6 & -32.0 \\
\hline Estonia & 36.6 & 51.3 & 11.6 & 37.2 & 15.1 & -22.1 \\
\hline
\end{tabular}

Source: Estonia - authors' calculations; other countries - Barnes, Haskel, Maliranta 2001.

Note. Productivity growth is measured over a 5-year horizon and the Griliches-Regev decomposition has been used. Productivity growth is measured as the percents of initial productivity level. All other numeric values are per cent of total productivity growth. 
Table 5. Decompositions of total factor productivity and labour productivity changes at different time horizons

\begin{tabular}{lcccccc}
\hline & $\begin{array}{c}\text { Productivity } \\
\text { growth }\end{array}$ & Within & Between & Net entry & Entry & Exit \\
\hline $\begin{array}{l}\text { LPQ, GR } \\
2 \text { years }\end{array}$ & 19.1 & 79.4 & 2.0 & 18.6 & -11.2 & -29.8 \\
3 years & 25.7 & 75.0 & -1.0 & 26 & -8.9 & -34.9 \\
5 years & 46.7 & 59.2 & -2.0 & 42.8 & 5.7 & -37.1 \\
TFP, GR & & & & & -1.2 & -22.6 \\
2 years & 20.6 & 43.2 & 35.4 & 21.4 & -5.3 & -40.6 \\
3 years & 22.0 & 45.0 & 19.7 & 35.3 & 15.1 & -22.1 \\
\hline 5 years & 36.6 & 51.3 & 11.6 & 37.2 & & \\
\hline
\end{tabular}

Source: Estonia - authors' calculations

Note. Productivity growth is measured as the percents of initial productivity level. All other numeric values are per cent of total productivity growth.

Table 6. Decompositions of labour productivity growth: changes over the time

\begin{tabular}{lccccccc}
\hline Industry & Year & $\begin{array}{c}\text { Productivity } \\
\text { growth }\end{array}$ & Within & Between & Net entry & Entry & Exit \\
\hline Agriculture & 1998 & 1.2 & -72.1 & 1866.5 & -1791.2 & & -96.8 \\
& 1999 & 8.0 & -58.0 & 135.2 & -2.5 & 35.4 & 10.2 \\
& 2000 & 30.3 & 49.8 & 33.8 & 3.2 & 12.2 & -0.9 \\
Manufacturing & 2001 & 36.0 & 76.8 & 27.3 & -16.3 & 12.0 & -0.1 \\
& 1998 & 30.6 & 49.9 & -1.2 & 1.0 & 3.0 & -47.4 \\
& 1999 & 23.5 & 105.0 & 9.2 & -29.3 & -3.9 & -19.0 \\
Construction & 2000 & 20.3 & 86.9 & 0.3 & -2.2 & -5.4 & -20.4 \\
& 2001 & 28.3 & 74.2 & 9.3 & -1.6 & 1.4 & -16.7 \\
Business & 1998 & 55.1 & 55.4 & 24.1 & -20.6 & 19.0 & -22.1 \\
services & 1999 & 23.0 & 60.1 & 26.3 & 10.0 & -10.4 & -14.0 \\
& 2000 & 20.0 & 85.0 & 35.7 & -20.8 & -18.7 & -18.8 \\
& 2001 & 11.3 & 81.8 & 41.7 & -39.3 & -36.0 & -51.9 \\
Public services & 1998 & 20.2 & 120.1 & -1.8 & -52.0 & 12.5 & -21.3 \\
& 1999 & 14.9 & 100.7 & 129.0 & -153.5 & -17.2 & -41.0 \\
& 2000 & 14.1 & 82.9 & 89.8 & -61.3 & -15.5 & -4.1 \\
Total economy & 1998 & 29.0 & 69.6 & 60.0 & -57.5 & -10.4 & -18.1 \\
& 1999 & 26.1 & 70.5 & 42.0 & -44.5 & 4.2 & -27.2 \\
& 2000 & 21.6 & 95.9 & 56.7 & -52.6 & -9.9 & -27.8 \\
& 2001 & 15.1 & 73.9 & 84.4 & -47.9 & -19.5 & -9.8
\end{tabular}

Note. Griliches-Regev decompositions of labour productivity change over 3-year horizons are presented. Productivity growth is measured as the percents of initial productivity level. All other numeric values are per cent of total productivity growth. 
Table 7. The contribution of entry and exit to labour productivity growth in different industries

\begin{tabular}{lccccccc}
\hline Industry & \multicolumn{2}{c}{$\begin{array}{c}\text { Share of the number } \\
\text { of plants }\end{array}$} & \multicolumn{2}{c}{ Employment share } & \multicolumn{3}{c}{ Relative labour productivity } \\
\cline { 2 - 8 } & Entrants & Exits & Entrants & Exits & Entrants & Exits & Continuer \\
\hline Manufacturing & 0.590 & 0.386 & 0.370 & 0.338 & 1.527 & 0.691 & 1.455 \\
Agriculture & 0.557 & 0.497 & 0.334 & 0.434 & 2.948 & 0.751 & 1.554 \\
Construction & 0.632 & 0.428 & 0.418 & 0.343 & 1.345 & 0.675 & 1.308 \\
Trade & 0.674 & 0.465 & 0.467 & 0.356 & 1.287 & 0.627 & 1.270 \\
Business services & 0.688 & 0.427 & 0.460 & 0.292 & 1.201 & 0.688 & 1.218 \\
Transport & 0.713 & 0.340 & 0.389 & 0.186 & 0.936 & 0.714 & 1.074 \\
Public services & 0.697 & 0.379 & 0.517 & 0.263 & 1.196 & 0.716 & 1.209 \\
TOT & 0.659 & 0.422 & 0.433 & 0.324 & 1.340 & 0.695 & 1.260 \\
\hline
\end{tabular}

Note. Relative labour productivity is defined as output per worker relative to that of continuing firms in the base period. The share of exiting firms reflects the share in the base year. The share of entering firms reflects the share in the end year. Productivity growth has been measured over a 5-year span.

Table 8. Productivity differentials in manufacturing, foreign owned versus domestic firms

\begin{tabular}{|c|c|c|c|c|c|c|}
\hline Firm status & $\begin{array}{l}\text { Ownership } \\
\text { variable }\end{array}$ & $\begin{array}{l}\text { Share of the } \\
\text { no. of plants }\end{array}$ & $\begin{array}{l}\text { Employment } \\
\text { share }\end{array}$ & $\begin{array}{l}\text { LP in the base } \\
\text { year relative to } \\
\text { continuers base } \\
\text { year }\end{array}$ & $\begin{array}{l}\text { LP in the end } \\
\text { year relative to } \\
\text { continuers base } \\
\text { year }\end{array}$ & $\begin{array}{l}\text { LP in the end } \\
\text { year relative to } \\
\text { continuers end } \\
\text { year }\end{array}$ \\
\hline \multirow[t]{2}{*}{ Exiting firm } & Domestic & 0.928 & 0.918 & 0.672 & & \\
\hline & Foreign & 0.072 & 0.082 & 1.123 & & \\
\hline \multirow[t]{2}{*}{ Entering firms } & Domestic & 0.888 & 0.817 & & 1.563 & 1.036 \\
\hline & Foreign & 0.112 & 0.183 & & 2.637 & 1.748 \\
\hline \multirow[t]{3}{*}{ Continuing firm } & Domestic & 0.871 & 0.741 & 0.894 & 1.356 & 0.899 \\
\hline & Foreign & 0.129 & 0.259 & 1.720 & 2.540 & 1.684 \\
\hline & All & & & 1.000 & 1.508 & 1.000 \\
\hline
\end{tabular}

Note. Productivity growth is measured over a 5-year span.

Table 9. Productivity decompositions: foreign owned versus domestic firms

\begin{tabular}{|c|c|c|c|c|c|}
\hline Firms & Within & Between & Entry & Exit & Net entry \\
\hline \multicolumn{6}{|c|}{ Manufacturing, LPQ } \\
\hline Domestic firms & 51.52 & 0.26 & -8.14 & -33 & 24.86 \\
\hline Foreign firms & 23.35 & -1.1 & -0.58 & -1.76 & 1.19 \\
\hline \multicolumn{6}{|c|}{ Manufacturing, TFP } \\
\hline Domestic firms & 19.07 & 15.2 & -11.3 & -34.73 & 23.44 \\
\hline Foreign firms & 25.87 & 4.51 & 5.72 & -6.06 & 11.77 \\
\hline \multicolumn{6}{|c|}{ Business services, LPQ } \\
\hline Domestic firms & 55.11 & 16.77 & -27.1 & -32.69 & 5.59 \\
\hline Foreign firms & 2.37 & 13.85 & 8.19 & 2.52 & 5.68 \\
\hline \multicolumn{6}{|c|}{ Business services, TFP } \\
\hline Domestic firms & -307.37 & 216.44 & -40.9 & -99.59 & 58.7 \\
\hline Foreign firms & 36.71 & 20.2 & 33.27 & 13.61 & 19.67 \\
\hline
\end{tabular}
Note. Productivity growth is measured over a 3-year span. The Griliches-Regev decomposition has been used. 


\section{Appendix}

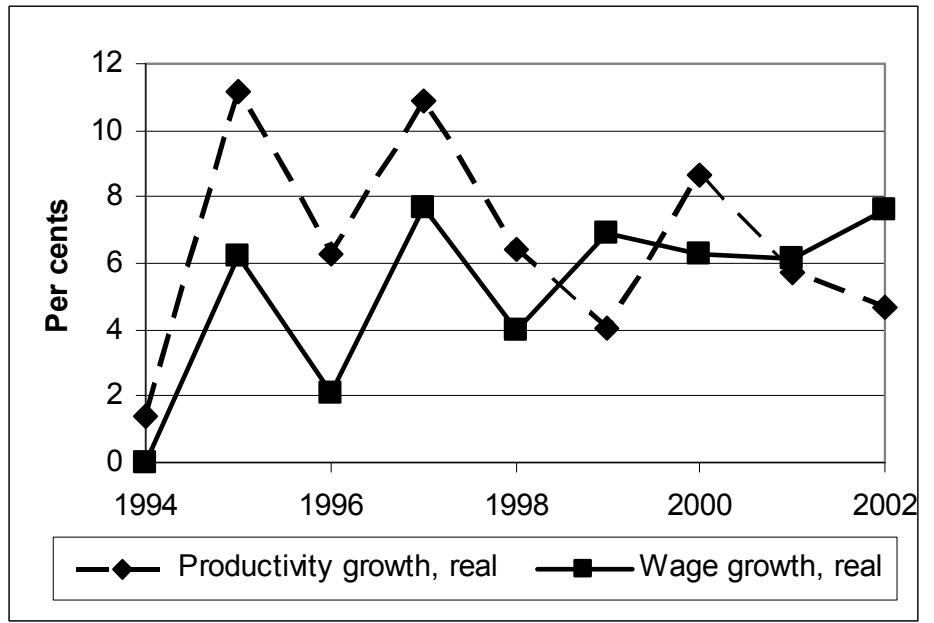

Figure A1 Productivity and wage growth in Estonia

Source: Authors' calculations; Statistical Office of Estonia, www.stat.ee

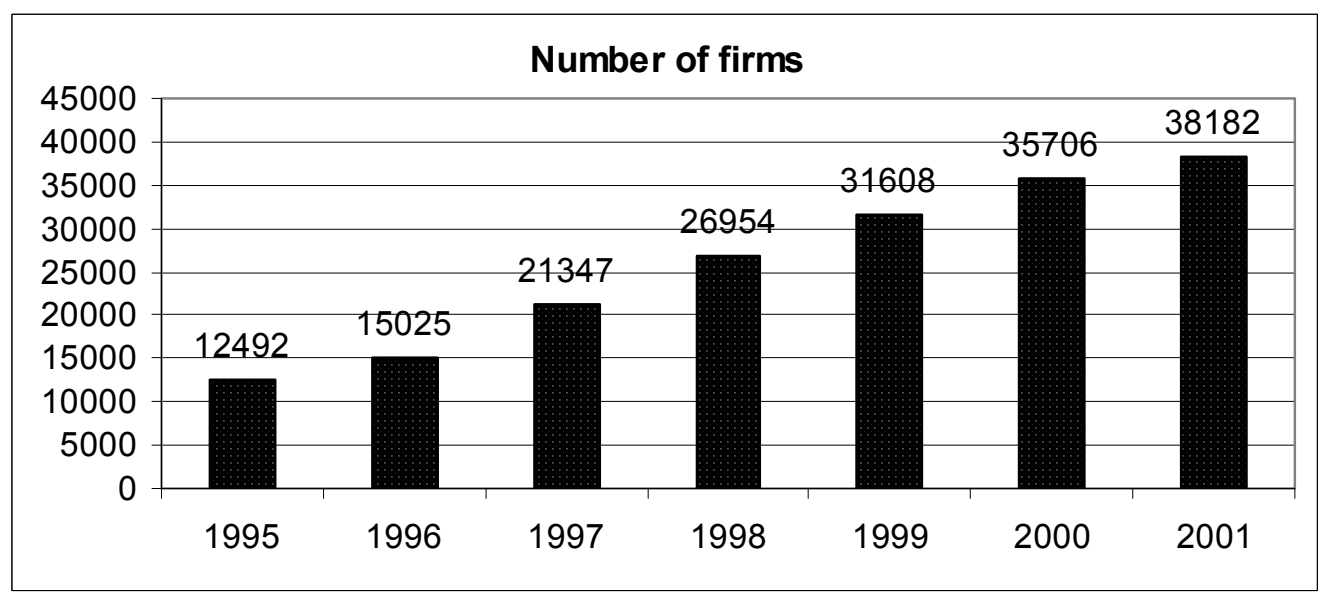

Figure A2. The evolution of the total number of firms in the Estonian Business Registry data

Source: Estonian Business Registry database, authors' calculations 
Table A1. Distribution of observations across employer size classes (all years)

\begin{tabular}{ccccccc}
\hline Size class & $\begin{array}{c}\text { Number of } \\
\text { employees }\end{array}$ & Frequency & Percent & $\begin{array}{c}\text { Cumulative } \\
\text { percent }\end{array}$ & $\begin{array}{c}\text { Employment } \\
\text { share }\end{array}$ & $\begin{array}{c}\text { Cumulative } \\
\text { employment } \\
\text { share }\end{array}$ \\
\hline 1 & 0 & 53529 & 23.35 & 23.35 & 0.00 & 0.00 \\
2 & $1-9$ & 74030 & 32.29 & 55.64 & 13.43 & 13.43 \\
3 & $10-19$ & 17697 & 7.72 & 63.36 & 11.28 & 24.71 \\
4 & $20-49$ & 12217 & 5.33 & 68.68 & 17.33 & 42.04 \\
5 & $50-99$ & 4325 & 1.89 & 70.57 & 13.96 & 56.00 \\
6 & $100-249$ & 2067 & 0.90 & 71.47 & 14.60 & 70.60 \\
7 & $250-449$ & 585 & 0.26 & 71.73 & 9.58 & 80.18 \\
\hline 8 & More than 500 & 316 & 0.14 & 71.86 & 19.82 & 100.00 \\
\hline 9 & Not available & 64506 & 28.14 & 100 & 0.00 & 100.00 \\
\hline
\end{tabular}

Source: Estonian Business Registry database, authors' calculations

Table A2. Changes in the number of firms in different industries (percents of the total number of firms)

\begin{tabular}{lccccccc}
\hline Industry & 1995 & 1996 & 1997 & 1998 & 1999 & 2000 & 2001 \\
\hline Agriculture & 7.8 & 7.11 & 6.45 & 5.61 & 5.18 & 4.99 & 4.63 \\
Mining and quarrying & 0.37 & 0.38 & 0.41 & 0.4 & 0.35 & 0.27 & 0.27 \\
Manufacturing & 17.3 & 16.59 & 16.95 & 16.56 & 16.52 & 15.79 & 15.47 \\
Electricity, gas and & & & & & & & \\
water supply & 1.75 & 1.42 & 1.33 & 1.31 & 1.26 & 1.06 & 0.95 \\
Construction & 9.05 & 8.87 & 8.35 & 8.42 & 8.26 & 7.92 & 7.84 \\
Private services & 58.59 & 60.59 & 61.75 & 62.44 & 62.8 & 64.19 & 64.7 \\
Public services & 5.15 & 5.05 & 4.75 & 5.26 & 5.63 & 5.79 & 6.13 \\
TOT & 100 & 100 & 100 & 100 & 100 & 100 & 100 \\
\hline
\end{tabular}

Source: Estonian Business Registry database, authors' calculations 
Table A3. Firm size across industries and time

\begin{tabular}{|c|c|c|c|c|c|}
\hline Industry & Year & $\begin{array}{c}\text { Mean } \\
\text { employment }\end{array}$ & $\begin{array}{c}\text { Standard deviation of } \\
\text { employment }\end{array}$ & $\begin{array}{c}\text { Coefficient of } \\
\text { variation }\end{array}$ & $\begin{array}{c}\text { Share of industry } \\
\text { employment in total } \\
\text { employment }\end{array}$ \\
\hline \multirow[t]{7}{*}{ Manufacturing } & 1995 & 37.6 & 141.1 & 3.8 & $33 \%$ \\
\hline & 1996 & 42.0 & 139.9 & 3.3 & $33 \%$ \\
\hline & 1997 & 44.1 & 139.1 & 3.2 & $32 \%$ \\
\hline & 1998 & 40.0 & 121.7 & 3.0 & $31 \%$ \\
\hline & 1999 & 35.8 & 105.5 & 2.9 & $31 \%$ \\
\hline & 2000 & 34.5 & 107.9 & 3.1 & $32 \%$ \\
\hline & 2001 & 32.6 & 125.7 & 3.9 & $32 \%$ \\
\hline \multirow[t]{7}{*}{ Agriculture } & 1995 & 23.4 & 37.5 & 1.6 & $9 \%$ \\
\hline & 1996 & 30.5 & 74.7 & 2.5 & $10 \%$ \\
\hline & 1997 & 29.8 & 76.0 & 2.5 & $8 \%$ \\
\hline & 1998 & 26.0 & 72.9 & 2.8 & $7 \%$ \\
\hline & 1999 & 20.1 & 40.3 & 2.0 & $6 \%$ \\
\hline & 2000 & 16.8 & 36.8 & 2.2 & $5 \%$ \\
\hline & 2001 & 16.2 & 36.7 & 2.3 & $5 \%$ \\
\hline \multirow[t]{7}{*}{ Services } & 1995 & 13.3 & 66.9 & 5.0 & $44 \%$ \\
\hline & 1996 & 14.4 & 69.7 & 4.8 & $45 \%$ \\
\hline & 1997 & 15.1 & 94.2 & 6.3 & $43 \%$ \\
\hline & 1998 & 14.0 & 87.3 & 6.2 & $45 \%$ \\
\hline & 1999 & 12.9 & 77.4 & 6.0 & $47 \%$ \\
\hline & 2000 & 11.7 & 66.5 & 5.7 & $48 \%$ \\
\hline & 2001 & 10.8 & 59.4 & 5.5 & $49 \%$ \\
\hline \multirow[t]{7}{*}{ Total economy } & 1995 & 19.4 & 82.8 & 4.3 & $100 \%$ \\
\hline & 1996 & 21.0 & 84.7 & 4.0 & $100 \%$ \\
\hline & 1997 & 23.4 & 139.5 & 6.0 & $100 \%$ \\
\hline & 1998 & 21.1 & 130.9 & 6.2 & $100 \%$ \\
\hline & 1999 & 18.9 & 108.9 & 5.8 & $100 \%$ \\
\hline & 2000 & 16.9 & 89.8 & 5.3 & $100 \%$ \\
\hline & 2001 & 15.6 & 85.8 & 5.5 & $100 \%$ \\
\hline
\end{tabular}

Source: Estonian Business Registry database, authors' calculations 
Table A4. Average firm size in Estonia and in OECD countries

\begin{tabular}{|c|c|c|c|c|c|}
\hline \multirow{2}{*}{$\begin{array}{l}\text { Industry: } \\
\text { stan code }\end{array}$} & \multirow{2}{*}{ Industry: description } & \multicolumn{2}{|c|}{ Mean employment } & \multicolumn{2}{|c|}{$\begin{array}{c}\text { Standard deviation of } \\
\text { employment }\end{array}$} \\
\hline & & Estonia & OECD average & Estonia & OECD average \\
\hline $1 \mathrm{t5}$ & Agriculture & 23.3 & 5.5 & 53.6 & 67.3 \\
\hline $10 \mathrm{t} 4$ & Mining and quarrying & 175.0 & 35.8 & 770.6 & 152.3 \\
\hline $15 \mathrm{t} 37$ & Total manufacturing & 38.1 & 40.8 & 125.8 & 350.8 \\
\hline $15 \mathrm{a} 6$ & Food products & 58.4 & 41.0 & 137.4 & 510.9 \\
\hline $17 \mathrm{t} 9$ & Textiles & 49.4 & 33.5 & 140.9 & 160.1 \\
\hline 20 & Wood products & 21.4 & 15.5 & 46.6 & 47.3 \\
\hline $21 \mathrm{a} 2$ & Pulp and paper & 19.8 & 33.4 & 45.4 & 176.5 \\
\hline 24 & Chemicals & 62.6 & 82.4 & 165.4 & 416.0 \\
\hline 26 & $\begin{array}{l}\text { Other non-metallic mineral } \\
\text { products }\end{array}$ & 41.9 & 30.3 & 77.6 & 158.5 \\
\hline $27 \mathrm{t} 33$ & Basic metals and machinery & 30.2 & 39.4 & 114.4 & 258.8 \\
\hline $34 \mathrm{a} 5$ & Transport equipment & 80.9 & 228.4 & 208.7 & 1525.9 \\
\hline $36 \mathrm{a} 7$ & Furniture, recycling & 44.1 & 20.3 & 144.4 & 105.3 \\
\hline $40 \mathrm{a} 1$ & $\begin{array}{l}\text { Electricity, gas and water } \\
\text { supply }\end{array}$ & 51.0 & 97.1 & 275.4 & 1388.8 \\
\hline 45 & Construction & 19.3 & 9.8 & 36.9 & 195.3 \\
\hline $50 \mathrm{t} 74$ & Business sector services & 13.1 & 16.3 & 77.2 & 382.2 \\
\hline $50 \mathrm{t} 5$ & $\begin{array}{l}\text { Wholesale and retail trade; } \\
\text { hotels }\end{array}$ & 10.6 & 14.5 & 25.8 & 280.9 \\
\hline $60 \mathrm{t} 4$ & Transport and communication & 30.7 & 26.9 & 204.9 & 831.8 \\
\hline $65 \mathrm{t} 74$ & Financial intermediation & 10.8 & 17.4 & 35.2 & 398.1 \\
\hline $75 \mathrm{t} 99$ & Public services & 13.7 & 23.5 & 29.0 & 2184.7 \\
\hline TOT & Total economy & 19.5 & 19.6 & 103.2 & 247.9 \\
\hline
\end{tabular}

Source: Estonian Business Registry database, authors' calculations

Table A5. The number of different kinds of transactions in the Business Registry data

\begin{tabular}{|c|c|c|c|c|c|}
\hline Transaction & Description & Frequency & Percent & $\begin{array}{l}\text { The average proportion of } \\
\text { firms involved weighted } \\
\text { by employment }\end{array}$ & $\begin{array}{l}\text { The average } \\
\text { proportion of } \\
\text { firms involved }\end{array}$ \\
\hline Predecessor & Change in firm id & 24418 & 97.53 & 69.5 & 49.3 \\
\hline Acquisition & $\begin{array}{l}2 \text { or more firms } \\
\text { merge, no new id }\end{array}$ & 366 & 1.46 & 3.9 & 0.5 \\
\hline Merger & $\begin{array}{l}2 \text { or more firms } \\
\text { merge, old firms } \\
\text { terminate and new } \\
\text { firm is formed }\end{array}$ & 191 & 0.76 & 2.2 & 0.2 \\
\hline Break up & $\begin{array}{l}\text { A firm is divided in } 2 \\
\text { or more pieces, old } \\
\text { firm is terminated }\end{array}$ & 17 & 0.07 & 0.1 & 0 \\
\hline Divestiture & $\begin{array}{l}2 \text { or more units } \\
\text { separate, old firm } \\
\text { continues }\end{array}$ & 39 & 0.16 & 1 & 0.1 \\
\hline $\begin{array}{l}\text { Unofficial } \\
\text { predecessor }\end{array}$ & & 5 & 0.02 & 0 & 0 \\
\hline No transaction & & - & - & 23.4 & 50 \\
\hline Total & & 25036 & 100.00 & 100 & 100 \\
\hline
\end{tabular}

Source: Estonian Business Registry database, authors' calculations 
Table A6. Decompositions of labour productivity change by industries in Estonia

\begin{tabular}{|c|c|c|c|c|c|c|c|}
\hline & $\begin{array}{l}\text { Productivity } \\
\text { growth }\end{array}$ & Within & Between & Covariance & $\begin{array}{c}\text { Net } \\
\text { entry }\end{array}$ & Entry & Exit \\
\hline \multicolumn{8}{|l|}{ FHK } \\
\hline Manufacturing & 46.7 & 61.0 & -1.8 & -3.6 & 44.3 & 24.1 & -20.2 \\
\hline Agriculture & 67.8 & 33.2 & 15.2 & 4.3 & 47.3 & 36.6 & -10.6 \\
\hline Construction & 50.5 & 55.5 & 17.1 & -12.9 & 40.3 & 20.2 & -20.2 \\
\hline Trade & 52.8 & 46.2 & 23.3 & -16.8 & 47.3 & 32.6 & -14.7 \\
\hline Business services & 28.2 & 97.3 & 27.2 & -69.0 & 44.5 & 26.2 & -18.4 \\
\hline Transport & -13.8 & 250.9 & 108.6 & -425.5 & -34.1 & -73.5 & -39.4 \\
\hline \multicolumn{8}{|l|}{ GR approach } \\
\hline Manufacturing & 46.7 & 59.2 & -2.0 & & 42.8 & 5.7 & -37.1 \\
\hline Agriculture & 67.8 & 35.4 & 12.4 & & 52.2 & 19.9 & -32.3 \\
\hline Construction & 50.5 & 49.0 & 14.4 & & 36.6 & -0.7 & -37.3 \\
\hline Trade & 52.8 & 37.8 & 20.5 & & 41.6 & 9.3 & -32.4 \\
\hline Business services & 28.2 & 62.8 & 1.1 & & 36.1 & 3.1 & -32.9 \\
\hline Transport & -13.8 & 38.2 & -114.4 & & -23.8 & -54.0 & -30.1 \\
\hline \multicolumn{8}{|c|}{ Baldwin 1 approach } \\
\hline Manufacturing & 46.7 & 61.0 & -3.6 & -3.6 & 46.2 & & \\
\hline Agriculture & 67.8 & 33.2 & 16.4 & 4.3 & 46.0 & & \\
\hline Construction & 50.5 & 55.5 & 12.7 & -12.9 & 44.7 & & \\
\hline Trade & 52.8 & 46.2 & 18.5 & -16.8 & 52.0 & & \\
\hline Business services & 28.2 & 97.3 & 16.9 & -69.0 & 54.9 & & \\
\hline Transport & -13.8 & 250.9 & 81.4 & -425.5 & -6.8 & & \\
\hline \multicolumn{8}{|c|}{ Baldwin 2 approach } \\
\hline Manufacturing & 46.7 & 59.2 & -5.4 & & 46.2 & & \\
\hline Agriculture & 67.8 & 35.4 & 18.6 & & 46.0 & & \\
\hline Construction & 50.5 & 49.0 & 6.3 & & 44.7 & & \\
\hline Trade & 52.8 & 37.8 & 10.1 & & 52.0 & & \\
\hline Business services & 28.2 & 62.8 & -17.7 & & 54.9 & & \\
\hline Transport & -13.8 & 38.2 & -131.4 & & -6.8 & & \\
\hline
\end{tabular}

Source: Estonian Business Registry database, authors' calculations

Note. Productivity growth is measured over a 5-year horizon. Productivity growth is measured as the percents of initial productivity level. All other numeric values are per cent of total productivity growth. 
Table A7. Decompositions of total factor productivity change by industries in Estonia

\begin{tabular}{|c|c|c|c|c|c|c|c|}
\hline & $\begin{array}{l}\text { Productivity } \\
\text { growth }\end{array}$ & Within & Between & Covariance & Net entry & Entry & Exit \\
\hline \multicolumn{8}{|l|}{ FHK approach } \\
\hline Manufacturing & 36.6 & 65.4 & 21.8 & -28.2 & 41.1 & 29.5 & -11.6 \\
\hline Agriculture & 44.9 & 6.2 & 23.2 & -3.3 & 73.8 & 52.3 & -21.5 \\
\hline Construction & 48.7 & 54.0 & 80.6 & -70.4 & 35.9 & 42.2 & 6.4 \\
\hline Trade & 21.3 & 51.1 & 86.5 & -129.6 & 92.1 & 55.3 & -36.8 \\
\hline Business services & 17.9 & 87.9 & 199.8 & -249.2 & 61.5 & 47.7 & -13.9 \\
\hline Transport & -30.7 & -105.8 & 57.7 & -56.1 & 4.2 & -24.3 & -28.6 \\
\hline \multicolumn{8}{|l|}{ GR approach } \\
\hline Manufacturing & 36.6 & 51.3 & 11.6 & & 37.2 & 15.1 & -22.1 \\
\hline Agriculture & 44.9 & 4.6 & 19.9 & & 75.5 & 33.2 & -42.3 \\
\hline Construction & 48.7 & 18.8 & 50.2 & & 31.0 & 23.4 & -7.6 \\
\hline Trade & 21.3 & -13.7 & 24.3 & & 89.4 & 36.6 & -52.8 \\
\hline Business services & 17.9 & -36.7 & 80.7 & & 56.1 & 29.2 & -26.8 \\
\hline Transport & -30.7 & -133.8 & 27.6 & & 6.3 & -9.6 & -15.8 \\
\hline \multicolumn{8}{|c|}{ Baldwin 1 approach } \\
\hline Manufacturing & 36.6 & 65.4 & 17.3 & -28.2 & 45.5 & & \\
\hline Agriculture & 44.9 & 6.2 & 24.1 & -3.3 & 72.9 & & \\
\hline Construction & 48.7 & 54.0 & 84.1 & -70.4 & 32.4 & & \\
\hline Trade & 21.3 & 51.1 & 79.5 & -129.6 & 99.1 & & \\
\hline Business services & 17.9 & 87.9 & 194.7 & -249.2 & 66.6 & & \\
\hline Transport & -30.7 & -105.8 & 53.0 & -56.1 & 8.9 & & \\
\hline \multicolumn{8}{|c|}{ Baldwin 2 approach } \\
\hline Manufacturing & 36.6 & 51.3 & 3.2 & & 45.5 & & \\
\hline Agriculture & 44.9 & 4.6 & 22.5 & & 72.9 & & \\
\hline Construction & 48.7 & 18.8 & 48.8 & & 32.4 & & \\
\hline Trade & 21.3 & -13.7 & 14.7 & & 99.1 & & \\
\hline Business services & 17.9 & -36.7 & 70.1 & & 66.6 & & \\
\hline Transport & -30.7 & -133.8 & 25.0 & & 8.9 & & \\
\hline
\end{tabular}

Source: authors' calculations

Note. The productivity growth is measured over a 5-year horizon. Productivity growth is measured as the percents of initial productivity level. All other numeric values are per cent of total productivity growth. 